\title{
La protección internacional del patrimonio cultural en caso de conflicto armado
}

\author{
Francesc Josep de Rueda Roigé \\ Universitat Autònoma de Barcelona \\ Departament d'Art \\ 08193 bellaterra (Barcelona). Spain
}

\begin{abstract}
RESUMEN
En los conflictos armados los bienes culturales han padecido toda suerte de infortunios, como queda constatado a través de un repaso de las vicisitudes por las que los mismos han pasado en el decurso del tiempo. En consecuencia, las organizaciones internacionales gubernamentales y no gubernamentales han encauzado sus esfuerzos en elaborar una reglamentación internacional encaminada a protegerlos. Tras analizar lo que debe entenderse por bienes culturales y la problemática que esta expresión comporta, se estudian las normas internacionales destinadas a la conservación y restitución de los mismos en el supuesto de una guerra, señalando las ventajas y defectos que esta normativa presenta.
\end{abstract}

Palabras clave:

patrimonio cultural, protección internacional, conflicto armado, legislación.

ABSTRACT

\section{International protection of the cultural heritage} in case of armed conflict

Cultural property has suffered all sorts of misfortunes because of armed conflicts, as one can easily verify by examining the vicissitudes which it has undergone throughout time. Therefore, the international organizations, both governmental and non-governmental, have geared their efforts towards producing international regulation which strives to protect such heritage. After analyzing the concept of cultural property and the problems posed by this expression, there follows a study of those international rules aiming at its preservation and restitution in case of war, pointing out the advantages and setbacks which that regulation may have.

Key words:

Cultural heritage, international protection, armed conflict, legislation. 


\section{Los bienes culturales durante los conflictos armados. Acotaciones previas}

Muchas son las obras artísticas que, en el decurso de los años, se han visto sometidas a un entresijo de peripecias que difícilmente podían haber sido profetizadas por sus comitentes o artífices. Las catástrofes naturales, como los terremotos o las erupciones volcánicas, han afectado a algunas piezas, pero son, sin duda, las acciones emprendidas por el ser humano las que han ocasionado los perjuicios y daños más graves, algunos irreparables. No sólo la polución producida por las industrias, los sistemas de calefacción y los medios de transporte ha hecho mella en algunas obras emblemáticas del pasado (piénsese por ejemplo en los diversos monumentos clásicos de Roma o Atenas, que provocaron hace ya algunos años la alarma internacional), sino que también, muchas veces con argumentaciones en pro del progreso y la civilización un tanto artificiosas, edificaciones de interés cultural han sucumbido para siempre. De todas maneras, el peor enemigo del patrimonio cultural son los conflictos armados, no sólo por los destrozos causados por los bombardeos, sino también por el vandalismo que con frecuencia emerge entre las tropas o el pueblo al ensañarse contra las obras artísticas u otras provistas de interés histórico, literario, científico..., y la codicia humana, que se cierne sobre diversos bienes, transportándolos, en ocasiones sin las condiciones necesarias, hacia determinados lugares en base a criterios de protección, conservación o salvamento, que las más de las veces enmascaran motivos bien distintos que, en última instancia, y hasta fechas no muy lejanas, se solían amparar en el botín de guerra legitimado por el derecho romano ${ }^{1}$.
Algunas de las piezas más célebres de toda la historia del arte, que desde sus inicios han causado gran admiración, se han visto desgraciadamente afectadas por este tipo de acontecimientos. Tal es el caso del Partenón, monumento debido a la voluntad de Pericles, donde intervinieron los mejores artistas de su época y realizado, pese a sus grandes dimensiones y extraordinaria riqueza escultórica, en el breve período de tiempo que media entre los años 447 aC y 432 aC. Su transformación en iglesia cristiana y, posteriormente, tras la conquista de Atenas por los turcos en el 1458, en mezquita, ocasionó en el mismo diversos cambios, que quedan minimizados si los comparamos con los producidos a raíz del episodio trágico que tuvo lugar en un fatídico 26 de septiembre del año 1687. En esta fecha una bomba de una batería veneciana prendió la pólvora almacenada por los turcos en el interior del edificio, provocando una tremenda explosión que lastimó irremediablemente para la posteridad gran parte de su estructura arquitectónica y decoración escultórica. El extremo occidental resultó prácticamente indemne, suerte que no duraría muchos años, puesto que, como ya hicieran los venecianos en el 1204, en que se llevaron del hipódromo de Constantinopla, como botín de guerra, los cuatro espléndidos caballos broncíneos, seguramente de época bajoimperial, para ubicarlos en la fachada de la catedral de San Marcos de Venecia ${ }^{2}$, ahora, tratando emular esa hazaña, intentaron hacer lo mismo con las figuras equinas marmóreas del frontón oeste del templo ateniense. Desgraciadamente, mientras bajaban las esculturas, la grúa se rompió, con lo que las mismas se fragmentaron en numerosos pedazos. Cuando poco después los turcos se volvieron a adueñar de Atenas, el progresivo deterioro del Partenón fue constante. Tan sólo me limitaré a resaltar el despojo efectuado a principios del siglo XIX de parte de su decoración escultórica, suceso protagonizado 
por Lord Elgin, a la sazón embajador británico ante Turquía, quien en 1816 la entregó a Gran Bretaña. Como contrapartida únicamente pidió que se le pagaran los gastos ocasionados con motivo de su traslado desde Atenas, cantidad que sólo le fue satisfecha parcialmente, por lo que quedó endeudado para el resto de sus días. Pese a las polémicas suscitadas con motivo de esta acción, que acarreó, por otro lado, que se destruyera una parte del entablamento, lo cierto es que, de no haber mediado esta intervención de Lord Elgin, es seguro que las esculturas que hoy podemos admirar en el Museo Británico (Londres) no se habrían conservado en ese estado, ya que los daños y las desapariciones continuaron, aun después de que los turcos se retiraran de Atenas (1833), como demuestra el cotejo entre los moldes hechos por Lord Elgin a inicios del siglo XIX y las fotografías realizadas menos de una centuria más tarde ${ }^{3}$.

Obras medievales tan conocidas como la abadía francesa de Moissac o la catedral de NotreDame de París sufrieron los embates de los conflictos acaecidos durante la Revolución Francesa. En aquélla, aparte de la destrucción de parte de su mobiliario, los soldados se dedicaron a hacer puntería contra la magnífica decoración escultórica de su claustro, que, gracias a una inscripción grabada en la cara oeste del pilar central de la panda occidental, sabemos que fue terminado en el año 1100. Respecto a la catedral parisina, debe mencionarse el derribo de las estatuas de la denominada «galería de los Reyes», dispuesta por encima de los tres

* Quiero hacer constar mi agradecimiento al profesor Joan Lluís Piñol Rull por sus valiosas sugerencias.

1. Uno de los casos de ocupación admitido por los romanos, que suponía, por tanto, la adquisición de la propiedad, estaba constituido por las cosas tomadas a los hostes (res hostium), como consecuencia de una campaña mili$\operatorname{tar}$ (occupatio bellica) e incluso fuera de ella, siempre y cuando no mediase un tratado de paz con Roma.

Según nos cuenta Gayo (Institutiones, II, 69), adquirimos por razón natural lo que cogemos al enemigo «Ea quoque, quae ex hostibus capiuntur, naturali ratione nostra fiunt» e incluso el mismo jurisconsulto (Institutiones, IV, 16) considera que la propiedad más legítima parece ser la de las cosas cogidas al enemigo «maxime sua esse credebant, quae ex hostibus cepissent", siendo la lanza el símbolo de la propiedad. Este criterio también aparece recogido en el Digesto $(41,1,5,7)$, ya que lo que se coge al enemigo se hace inmediatamente, por derecho de gentes, de quien lo toma «Item quae ex hostibus capiuntur, iure gentium statim capientium fiunt», señalándose, además (48
$13,15)$, que el que sustraiga el botín capturado al enemigo responde por la ley del peculado y es condenado al cuádruplo «Is, qui praedam ab hostibus captam subripuit, lege peculatus tenetur et in quadruplum damnatur». En las Institutiones de Justiniano (2, $1,17)$ también se halla establecido que las cosas cogidas a los enemigos se hacen inmediatamente nuestras por derecho de gentes «Item ea, quae ex hostibus capimus, iure gentium statim nostra fiunt».

$\mathrm{La}$ antinomia existente en las fuentes en relación con la pertenencia de los bienes al Estado o al primer ocupante puede resolverse distinguiendo entre el botín conseguido tras una campaña militar, que pertenece al Estado, y el apoderamiento individual de cosas concretas u objetos singulares de gentes no amigas de Roma, que pertenecen al primer ocupante (J. Arias Ramos ; J. A. Arias Bonet, Derecho Romano. I. Parte General. Derechos Reales, Editorial Revista de Derecho Privado-Editoriales de Derecho Reunidas, Madrid, 1986, $18^{\mathrm{a}}$ ed., p. 247).

2. Posteriormente, en 1797 , Napoleón se los llevó a París, donde unos años después sirvie-

portales de la fachada de los pies, por considerarse que representaban a los monarcas franceses cuando en realidad figuraban a los veintiocho reyes de Judá, antepasados de Cristo, de los que en 1977 se encontraron importantes restos, conservados actualmente en el Museo de Cluny (París) ${ }^{4}$.

Los perjuicios ocasionados al partrimonio cultural, lejos de haber cesado, se han ido sucediendo, pese a la voluntad de algunos por evitarlo, durante el siglo xx. La Primera Guerra Mundial (19141918), la guerra civil española (1936-1939) y la Segunda Guerra Mundial (1939-1945) son sólo algunos de los conflictos que están presentes en las mentes de muchos de nosotros, tanto por las víctimas ocasionadas como por la ruina de parte del conjunto de los bienes culturales. Especialmente virulenta fue, en este sentido, la Segunda Guerra Mundial. Polonia fue uno de los países que más se vio afectado, en tanto en cuanto Hitler, pretendiendo eliminar totalmente su cultura, no dudó en ordenar la destrucción de muchos de sus monumentos. Pero los destrozos se sucedieron por todas partes: derribo de la biblioteca de la Universidad de Lovaina, poco después de haber sido sido restaurada tras los estragos sufridos por la Primera Guerra Mundial; demolición de la abadía de Monte Cassino; pérdida de gran parte del ciclo pictórico de la Capilla Ovetari en la iglesia de los Eremitani de Padua, donde intervino Andrea Mantegna; etc. En ocasiones ciudades enteras fueron prácticamente arrasadas, como, por ejemplo, Dresde, y otras escaparon milagrosamente de tales

ron para coronar el arco del Carrousel, hasta que en 1815 fueron devueltos a Venecia. En el siglo xx, como consecuencia de la Primera y Segunda Guerra Mundiales, tuvieron que ser bajados nuevamente por temor a que fueran lastimados, para depositarlos provisionalmente en lugares más seguros. Sobre este aspecto, así como en relación con los problemas iconográficos, estilísticos, técnicos y cronológicos que han suscitado estos bronces, véase el conjunto de estudios recogidos en The Horses of San Marco. Venice, Olivetti, Milán, 1979. La trayectoria histórica también aparece expuesta, aunque muy brevemente, en John Boardman, El arte griego, El mundo del arte, núm. 4, Destino, Barcelona, 1991 (ed. original: 1967), p. 10-11. De manera más monográfica han sido estudiados por Vittorio Galliazzo en I cavalli di San Marco, Treviso, 1981, y «Die Pferde von San Marco: griechisch oder römisch?», Boreas, vol. 8 (1985), p. 49-80, así como por Michael JACOFF, en The Horses of San Marco and the Quadriga of the Lord, Princeton, 1993. Sobre la significación que tuvo para los venecianos el haberse adueñado de estos caballos, véase el sugerente estudio de Salvatore SETTIS
«Des ruines au musée. La destinné de la sculpture classique», Annales (Économies, Sociétés, Civilisations), año $48^{\circ}$ núm. 6 (1993), p. 1.347-1.380, concretamente las p. $1.355,1.357$ y 1.366. La polución atmosférica ha hecho que en 1983 estas esculturas se trasladasen al Museo Marciano en la propia basílica de San Marcos (Guido Perocco, "History of the treasury of San Marco", The Treasure of San Marco. Venice, Olivetti, Milán, 1984 , p. 65-68, concretamente la pàgina. 68).

3. La bibliografía existente sobre el Partenón es muy abundante. Uno de los libros más recientes, que recoge las obras esenciales publicadas con anterioridad, es el de Robin Francis RHodes, Architecture and Meaning on the Athenian Acropolis, Cambridge University Press, Cambridge, 1995. Sumamente útil es la pequeña monografía de Susan Woodford, El Partenón, Akal, Torrejón de Ardoz (Madrid), 1990 (ed. original: 1981); sobre las vicisitudes por las que ha pasado el Partenón a lo largo de la historia, véanse las páginas 41-47.

En relación con la controvertida cuestión suscitada por la reclamación por parte de Grecia de las esculturas del Partenón que hoy día detenta el Museo Británico, me remito a Jeanette GREENFIELD, The Return of Cultural Treasures, Cambridge University Press, Cambridge, 1996 ( $2^{\mathrm{a}}$ ed.; ed. original: 1989), p. 42-90. Muy recientemente la UNESCO ha vuelto a recomendar el retorno a Grecia de los mármoles del célebre monumento, acto que no parece haber sensibilizado la opinión contraria que desde años viene manteniendo la delegación británica.

4. Para conocer los estragos y el destino que padecieron diversas obras artísticas en los conflictos habidos desde la antigüedad hasta finales del siglo XviII en el marco geográfico europeo, véase Pietro VERri, «La suerte de los bienes culturales en los conflictos armados. De la Antigüedad a la Segunda Guerra Mundial (I)», Revista Internacional de la Cruz Roja, núm. 68 (1985), p. 67-85. En relación con los pillajes que sufrieron las obras de arte en la Pars Occidentis durante la época altomedieval, donde se trata también la cuestión de los tesoros escondidos, véase Michelangelo Cagiano de Azevedo, «Le opere d'arte nei bottini di guerra», Ordinamenti militari in Occidente nell'Alto Medioevo, t. II, Settimane di Studio del Centro Italiano di Studi sull'Alto Medioevo, XV, Centro Italiano di Studi sull'Alto Medioevo, Spoleto, 1968 , p. $1.101-1.126$, con la correspondiente discusión en las páginas 1.211-1.216. 
5. Muy interesate es la lectura de Lynn H. Nicholas, The Rape of Europa. The Fate of Europe's Treasures in the Third Reich and the Second World War, Vintage Books, Nueva York, 1995 (ed. original: 1994; traducido al francés por Éditions du Seuil, París, 1995, y al español por Destino, Barcelona, 1996), donde la autora expone detalladamente los preparativos realizados en algunos de los grandes museos europeos y norteamericanos en las vísperas del estallido del coflicto bélico llevando las obras artísticas hacia lugares más seguros, así como los saqueos y los bombardeos acae cidos en el transcurso de la guerra y, una vez que ésta hubo finalizado, los intentos de recuperación y restitución de los bienes incautados. En relación con los principales monumentos destruidos total o parcialmente en el transcurso de la Segunda Guerra Mundial, me remito a Henry LA FARge, Los tesoros perdidos de Europa, Seix Barral, Barcelona 1950 (ed. original: 1946), donde se recoge un amplio repertorio fotográfico sobre el estado de los mismos antes de sufrir los daños.

6. Tomislav SOLÁ, «El patrimoni i la guerra a Croàcia», $D e M u$ seus. Quaderns de Museologia i Museografia, núm. 4 (1.993), p. 14-19; Borislav SuRDIC, «Les profundes arrels de la destruc ció», De Museus. Quaderns de Museologia i Museografia, núm 4 (1993), p. 20-23; Alain-Charles LEFĖVRE, «Reportage: Bosnie et Croatie, un désastre culturel sans précédent", Archéologia, núm. 328 (1996), p. 26-35.

7. Stanislaw E. NAHLiK, «La protection internationale des biens culturels en cas de conflit armé», Recueil des Cours, t. 120 (1967-I), p. 61-163, concretamente la p. 89; Manlio Frigo, $L a$ protezione dei beni culturali nel diritto internazionale, Università di Milano, Pubblicazioni della Facoltà di Giurisprudenza, serie II, Studi di diritto internazionale, n. 7, A. Giuffrè Editore, Milán, 1986, página 72 (nota 16).

8. Yoshiaki IsHIZAWA, «État actue des monuments angkoriens" Dossiers Histoire et Archéologie, núm. 125 (1988), p. 102-105.

9. Alain-Charles LeFÈvre, "La Renaissance d'Angkor». Archéologia, núm. 324 (1996), p. 18-25.

10. Sobre las controversias surgi das a raíz de la reconstrucción de centro de la ciudad de Beirut tras sufrir la acción devastadora de la guerra y el trato que han merecido los valiosos restos arqueológicos allí hallados, véase AlainCharles LeFÈVRE, «Beyrouth: 1 plus grand chantier d'archéologie urbaine au monde», Archéologia núm. 316 (1995), p. 14-33; Jean LAUFFRAY, «Beyrouth: ce qui n'a pas été dit», Archéologia, núm. 317 (1995), p. 4-11; Alain-Char les LEFÉVR, «Beyrouth; l'archéologie par le vide.

embates, siendo París el caso más sobresaliente ${ }^{5}$. Muy recientemente la guerra ocurrida en la ex Yugoslavia ha demostrado una vez más que, a pesar de los esfuerzos, los estragos al patrimonio cultural continúan. Los destrozos producidos a raíz de este conflicto son de una amplitud enorme, habiéndose podido constatar que, como ya ocurriera con Hitler durante la Segunda Guerra Mundial, en no pocos casos lo que en realidad se pretendía era eliminar las trazas culturales de determinadas etnias. Banja Luka, Foca, Srebenica, Breko, Bjelina, Zvornik, Sarajevo, Mostar, Pocitelj, Stolac, Zagreb y un largo etcétera son testimonios mudos, pero explícitos, de los daños causados al patrimonio cultural. Especialmente manifiesto es, en este sentido, el caso de Dubrovnik, ciudad inscrita en la Lista del Patrimonio mundial en el año 1980 y que fue contundentemente bombardeada por la armada federal yugoslava durante 1991 y 1992, pese a la indignación y las amenazas de la comunidad internacional; el resultado fue que más de quinientos edificios del centro histórico se vieron en mayor o menor medida afectados, contándose entre ellos diversos palacios, conventos e iglesias ${ }^{6}$.

Si de Occidente pasamos a Oriente el panorama no es mucho más alentador. Uno de los episodios más execrables sobrevino en 1860, en el transcurso de la tercera "guerra del opio», cuando las tropas anglofrancesas incendiaron y destruyeron intencionadamente, bajo las órdenes expresas del embajador británico, una de las más ricas colecciones de arte oriental del mundo entero, que se albergaba en una serie de palacios y pabellones que constituían la residencia de verano del emperador chino $^{7}$. Del presente siglo baste recordar los tristes sucesos acaecidos en Camboya, primero inmersa, a partir de 1970, en una guerra civil, y unos pocos años más tarde, en un conflicto armado contra sus vecinos vietnamitas que no se ha resuelto hasta los años noventa. Aparte de los daños resultantes con motivo del abandono de las obras de arte y de la reutilización de algunas zonas monumentales como áreas para el cultivo del arroz, numerosas fueron las piezas que se destruyeron con el armamento bélico, algunas de ellas ex profeso, como así ocurrió con varias estatuas y relieves del templo de

Archéologia, núm. 318 (1995), p. 4-9; y François Villeneuve, «Archéologie à Beyrouth: le rôle de l'IFAPO» (con contestación de Jean Lauffray), Archéologia, núm. 321 (1996), p. 9.

11. Lluís Monreal i Agustí, Estratègies internacionals per a la conservació del patrimoni cultural, I945-1995 (con discurso de respuesta por Joan Bassegoda i Nonell), Reial Acadèmia Catalana de Belles Arts de Sant Jordi, Barcelona, 1996, p. 11-12.
12. Edward Burnett Tylor, Cultura primitiva. I / Los orígenes de la cultura, Ayuso, Madrid, 1977, p. 19 (ed. original: 1871).

13. Jean-Pierre Colin y Jack LANG, «La culture entre les peuples et les États: vers un nouveau droit international», Mélanges offerts à Charles Chaumont. Le droit des peuples à disposer d'eux-mêmes. Méthodes d'analyse $d u$ droit international, Éditions A. Pedone, París, 1984, p. 179-206. Para un estudio de la protección internacional de los bienes

Angkor $\mathrm{Vat}^{8}$. Actualmente los problemas más acuciantes, en relación con el patrimonio cultural, consisten en la gran cantidad de minas antipersona que aún existen esparcidas por toda Camboya, algunas de ellas dispuestas en el interior de los templos khmer, y en las acciones de pillaje9. También podemos recordar la guerra civil libanesa (19751990), con la destrucción de varios testimonios de época fenicia situados en Tiro y los daños ocasionados al Museo Nacional de Beirut, que hace algunos meses ha reabierto parcialmente sus puertas después de haberse llevado a cabo las primeras restauraciones ${ }^{10}$. Más recientemente no hay que olvidar el saqueo e incendio que sufrió el Museo $\mathrm{Na}$ cional de Kuwait por parte de los invasores de Irak (agosto de 1990), como tampoco la destrucción de diversos yacimientos arqueológicos de Mesopotamia y varias mezquitas iraquíes, que tuvo lugar unos meses más tarde de la mano de las fuerzas conjuntas occidentales durante la operación denominada «Tormenta del Desierto» ${ }^{11}$.

Como en otros campos en los que se ha desarrollado una protección internacional de intereses colectivos (derechos humanos, medio ambiente, etc.), la protección internacional del patrimonio cultural ha estado precedida por una legislación protectora en el ámbito de los ordenamientos estatales. Ha sido la comprobación de las limitaciones de esta legislación interna para lograr una protección adecuada la que ha impulsado el desarrollo de una normativa internacional, que por otra parte tampoco ha sido un obstáculo definitivo a las agresiones del patrimonio, a la vista de los conflictos armados más recientes y a los que ya nos hemos referido anteriormente.

El enfoque adoptado por las legislaciones estatales ha consistido en configurar una determinada categoría de bienes, los denominados «bienes culturales», los cuales, por su valor artístico, histórico o cultural, gozan de un régimen jurídico diferenciado que tiene una finalidad protectora y tutelar.

En los últimos tiempos se registra una tendencia, tanto en el ámbito interno como internacional, a utilizar la expresión «patrimonio cultural», u otras parecidas como «patrimonio histórico-artístico»o «patrimonio arqueológico, histórico y artístico»,

culturales en el marco de la cooperación cultural internacional, véase Liudmila Galenskaya, «International Co-operation in Cultural Affairs", Recueil des Cours, t. 198 (1986-III), p. 265331

14. Para el convenio constitutivo de la UNESCO, véase United Nations Treaty Series / Nations Unies. Recueil des Traités, vol. 4 , p. 275 y s.; UNESCO, ¿ Qué es la Unesco?, UNESCO, París, 1969, p. 69-73; Fernando Fuentes Bodelón, Calidad de vida, me- dio ambiente y ordenación del territorio. Textos internacionales, vol. III, CEOTMA-CIFCA, Madrid, 1982, p. 688-691 (el texto está incompleto); José Juste Ruiz- Romualdo Bermejo GARCíA, Organizaciones internacionales universales del sistema de las Naciones Unidas. Convenios constitutivos, Práctica Jurídica, Tecnos, Madrid, 1993, p. 250-256.

15. UNESCO, Final Act of the Intergovernmental Conference on the Protection of Cultural Property in the Event of Armed 
que tienen un significado globalizador mediante el que se hace referencia a todos los bienes sometidos a una determinada normativa protectora.

En un sentido lato, la protección jurídica del patrimonio cultural tendría que hacer referencia a las normas jurídicas protectoras de cualquier manifestación de la cultura. Si se adoptara la clásica definición de «cultura», que en el siglo pasado formuló el antropólogo Edward B. Tylor, como «ese complejo conjunto que incluye el conocimiento, las creencias, las artes, la moral, las leyes, las costumbres y cualesquiera otras aptitudes y hábitos adquiridos por el hombre como miembro de la sociedad» ${ }^{12}$, la noción de «patrimonio cultural» debería comprender muchas manifestaciones distintas de los «bienes culturales» propiamente dichos. Desde esta perspectiva amplia habría que incluir las lenguas, la literatura, la música, la danza, los conocimientos científicos, las fiestas populares, las prácticas religiosas... de todos los pueblos. No han faltado intentos de formular principios jurídicointernacionales que contemplan la cultura desde esta perspectiva amplia. La Conferencia General de la UNESCO, en su decimocuarta sesión, aprobó por unanimidad el 4 de noviembre de 1966, la «Declaración de principios de la cooperación cultural internacional», en la que se proclaman el principio de la igualdad de las culturas, el principio de que la cultura debe estar al servicio de la paz y del desarrollo de relaciones pacíficas y amistosas entre los Estados, el principio de que la cooperación cultural debe basarse en la reciprocidad y ser mutuamente beneficiosa y el principio de la protección de los bienes culturales, tanto en tiempo de paz como de guerra. Sobre la base de estas formulaciones y de la práctica internacional en el ámbito de la cooperación cultural, se ha postulado un nuevo derecho internacional de la cultura ${ }^{13}$.

En este artículo se considerará la protección del patrimonio cultural desde una perspectiva más restringida y limitada al régimen jurídico que se deriva de la práctica internacional de los tratados internacionales y de la acción de las organizaciones internacionales en la tutela de los bienes culturales en caso de conflicto armado. En relación con éstos, las normas internacionales han tenido un desarrollo diferenciado según se refirieran a tiempo de paz o de conflicto armado. En el estudio de dichas normas el enfoque generalmente adoptado consiste en exponer, en primer lugar, las normas de protección de los bienes culturales desarrolladas en el ámbito del derecho de guerra y examinar después las normas aplicables en tiempo de paz. Actualmente esta distinción es en parte artificial, puesto que la protección en tiempo de conflicto armado no puede ser eficaz, y así se reconoce expresamente en el preámbulo de la Convención de La Haya de 1954 para la protección de bienes culturales en tiempo de conflicto armado, «a menos que se organice en tiempo de paz», que es cuando han de adoptarse medidas decisivas tanto en la esfera nacional como internacional. No obstante, por razones de espacio, nos limitaremos en esta ocasión al régimen jurídico internacional protector del patrimonio cultural en el transcurso de una guerra.

Las normas internacionales de protección del patrimonio cultural tienen, o pueden tener, estas funciones: 1) la conservación, en sentido del mantenimiento de la integridad física, de los bienes culturales; 2) la restitución de los bienes a sus legítimos titulares, cuando han sido ilícitamente privados de su posesión, o a los países de procedencia, cuando han sido ilegalmente trasladados, y 3) el retorno, en el sentido de recuperación de los bienes culturales por un determinado Estado en atención a la importancia fundamental de dichos bienes para la integridad del patrimonio cultural de dicho Estado, a pesar de la posible legalidad que pudiera rodear las circunstancias de su salida. Se trata de funciones distintas, que normalmente corresponden a normas diferenciadas, pero eventualmente pueden coexistir simultáneamente en una misma norma.

\section{La reglamentación internacional protectora del patrimonio cultural. Actividad de las organizaciones internacionales}

La cooperación internacional para la protección del patrimonio cultural tiene su marco específico, en el ámbito universal, en la Organización de las $\mathrm{Na}$ ciones Unidas para la Educación, la Ciencia y la Cultura (UNESCO). El artículo I.2.c) de su Constitución le encomienda la función de contribuir a la conservación, el progreso y la difusión del saber, que realizará «velando por la conservación y la protección del patrimonio universal de libros, obras de arte y monumentos de interés histórico o científico, y recomendando a las naciones interesadas las convenciones internacionales que sean necesarias para tal fin» ${ }^{14}$. La UNESCO ha elaborado los principales convenios de protección del patrimonio cultural: el Convenio para la protección de los bienes culturales en caso de conflicto armado, hecho en La Haya el 14 de mayo de $1954^{15}$; la Convención sobre las medidas que deben adoptarse para prohibir e impedir la importación, la exportación y la transferencia de propiedad ilícitas de bienes culturales, hecha en París el 17 de noviembre de $1970^{16}$; la Convención para la protección del patrimonio mundial cultural y natural, hecha en París el 23 de noviembre de $1972^{17}$. A esta labor normativa hay que añadir diversas recomendaciones sobre distintos aspectos de la protección
Conflict, The Hague, I954, UNESCO, París, s.a., en donde, aparte del acta final, aparecen los textos de la convención, del reglamento para su aplicación, del protocolo y de las tres resoluciones adoptadas por la Conferencia, redactados en inglés, español, francés y ruso; United Nations Treaty Series/Nations Unies. Recueil des Traités, vol. 249, núm. 3.511 (1956), p. 215-386; Fernando Fuentes Bodelón, Calidad de vida, medio ambiente y ordenación del territorio. Textos internacionales, vol. II, CEOTMACIFCA, Madrid, 1982, p. $1.053-$ 1.060; FrIGO, op. cit., p. 363-387. En España: $B O E$ núm. 282, de 24 de noviembre de 1960. Para el texto de los principales convenios y recomendaciones de la UNESCO, en materia de bienes culturales, véase Conventions et recommandations de l'Unesco relatives à la protection $d u$ patrimoine culturel, UNESCO, París, 1983; para este convenio, véase las páginas 17-33 y para su reglamento de ejecución, protocolo y resoluciones de la Conferencia cf. las páginas 34-50. En relación con la legislación aplicable a nuestro país, en la materia que estamos tratando, véase $L e-$ gislació sobre patrimoni cultural, Legislació temàtica, núm. 7, Generalitat de Catalunya, Departament de Cultura, Barcelona, 1995; para este convenio véanse las páginas 275-285.

16. Naciones Unidas. Anuario Jurídico (1970), p. 132-140; American Journal of International Law, vol. 65 (1.971), p. 887895; International Legal Materials. Current Documents, vol. X, núm. 2 (1971), p. 289-293; United Nations Treaty Series / Nations Unies. Recueil des Traités, vol. 823, núm. 11.806 (1972), p. 231-275; Bonnie Burnham, La protection $d u$ patrimoine culturel. Manuel de législations nationales, Conseil International des Musées, París, 1974, p. 187-197; FuENTES BODELón, op. cit., vol. II, p. 1.100-1.105; Conventions et recommandations de l'Unesco..., p. 61-73; Ridha FraOUA, Le trafic illicite des biens culturels et leur restitution. Analyse des réglementations nationales et internationales. Critiques et propositions, Travaux de la Faculté de Droit de l'Université de Fribourg, Suisse, núm. 68, Éditions Universitaires Fribourg Suisse, Friburgo, 1985, p. 223233; FrIGO, op. cit., p. 393-401. En España: $B O E$ núm. 31, de 5 de febrero de 1986. Legislació..., p. 301-308.

17. International Legal Materials. Current Documents, vol. XI, núm. 6 (1972), p. 1.358-1.366; Naciones Unidas. Anuario Jurídico (1972), p. 90-101; Fuentes Bodelón, op. cit., vol. II, p. 1.114-1.121; Conventions et recommandations de l'Unesco... p. 79-97; FRIGO, op. cit., p. 405418. En España: BOE núm. 156, de 1 de julio de 1982 . Legislació..., p. 290-300. 
18. Véase el «Informe Preliminar sobre los medios jurídicos para la protección y conservación del patrimonio histórico y artístico de los países americanos». Documento CJI-6, p. 71-86. Reproducido en el documento Identificación, protección y vigilancia del patrimonio arqueológico, histórico y artístico de las naciones ame ricanas, junio de 1975, Doc. OEA / Ser. Q / II. 13; CJI-23, p. 125 140. Los textos de los convenios en páginas 117-124.

19. Pan American Union Treaty Series, núm. 47; International Legal Materials. Current Documents, vol. 15, núm. 6 (1976), p. 1.350-1.355; FraOUA, op. cit., p. 234-240.

20. European Treaty Series/Série des Traités européens, núm. 18 (1973), passim; Fuentes BODELÓN, op. cit., vol. II, p 1.061-1.063. España: $B O E$ núm. 204, de 10 de agosto de 1957.

21. International Legal Materials. Current Documents, vol. VIII, núm. 4 (1969), p. 736-740; FuENTES BODELón, op. cit., vol. II, p 1.098-1.100; European Treaty Se ries / Série des Traités européens. núm. 66 (1989), passim. España $B O E$ núm. 160 , de 5 de julio de 1975. Ricardo GuTIÉRREZ NieTO Ley de Protección del Patrimonio Histórico Artístico, Cuadernos d Documentación, núm. 28, Presidencia del Gobierno, Secretaría General Técnica, Subdirecciór General de Documentación, Madrid, 1980, p. 56-60; Legislació... p. 286-289.

22. International Legal Materials. Document Highlights, vol. XXV, núm. 1 (1986), p. 4455; European Treaty Series / Série des Traités européens, núm. 119 (1990), passim

23. International Legal Materials Document Highlights, vol. XXV, núm. 2 (1986), p. 380-386; European Treaty Series / Série de. Traités européens, núm. 121 (1990), passim. España: $B O E$ núm. 155, de 30 de junio de 1989 Legislació..., p. 309-315.

24. Journal officiel des Communautés européennes Législation, núm. L 175 (5 de julio de 1985), p. 40-48.

25. Para profundizar en la protección que el patrimonio cultural goza en el derecho comunitario. véase Anne Derout, La protection des biens culturels en droit communautaire, Publications $\mathrm{d}$ Centre de Recherches européennes, Série Études, Édition Apogée, Rennes, 1993, passim, y Luis Martín Rebollo, El Comercio del Arte y la Unión Euro pea. La legislación española del patrimonio bistórico y el mercado interior: La normativa comunitaria sobre exportación y tráfico de bienes culturales, Cuadernos $\mathrm{de}$ Estudios Europeos, núm. 15, Fundación Universidad EmpresaCivitas, Madrid, 1994, p. 67 y s. del patrimonio cultural que los Estados miembros tienen la obligación de someter a sus autoridades competentes dentro del plazo de un año a contar desde la clausura de la Conferencia General en la cual hubieran sido aprobadas (art. IV.4 de la Constitución de la UNESCO) y sobre cuyo curso también tienen la obligación de informar a la Organización (art. VIII de la Constitución de la UNESCO). Dichas recomendaciones contribuyen a estimular la cooperación internacional a través de su aplicación en los derechos internos y a la formación de reglas consuetudinarias en esta materia.

En el ámbito regional destaca el temprano interés de los Estados del continente americano por la protección del patrimonio cultural de dichos países. La Segunda Conferencia Internacional americana, celebrada en la ciudad de México en marzo de 1902, aprobó una recomendación en la que se proponía la creación de una comisión arqueológica internacional americana que debía velar por la exploración y conservación de los principales conjuntos precolombinos y propiciar la creación de un «museo internacional americano» que coordinaría los trabajos de investigación. Aunque dicha recomendación no llegó a cristalizar en realizaciones concretas, después de diversas recomendaciones emitidas por las conferencias internacionales americanas, el Consejo Directivo de la Unión Panamericana preparó dos proyectos de convenciones que se abrieron a la firma el 15 de abril de 1935 en la ciudad de Washington. Uno de ellos constituía el Tratado para la protección de las instituciones artísticas y científicas, así como de los monumentos históricos (Pacto Roerich), que pretendía proteger los monumentos, especialmente en el curso de hostilidades militares, y otro era el Tratado sobre protección de muebles de valor histórico, que perseguía frenar el tráfico ilícito ${ }^{18}$. El Consejo Interamericano para la Educación, la Ciencia y la Cultura, desde su primera reunión en Viña del Mar (Chile) en 1970, impulsó la celebración de un convenio que actualizara las normas en esta materia. Fruto de este propósito fue la Convención sobre la protección del patrimonio arqueológico, histórico y artístico de los Estados americanos, hecha en San Salvador el 16 de junio de $1976^{19}$, inspirada en la Convención de la UNESCO de 1972.

La cooperación desarrollada en el marco del Consejo de Europa tiene su fundamento en el Convenio cultural europeo, hecho en París el 19 de diciembre de 1954, por el que los Estados contratantes se comprometen a adoptar «las medidas convenientes para salvaguardar su aportación al patrimonio cultural común de Europa y fomentar su desarollo» $(\text { art. 1) })^{20}$. La labor normativa del Consejo de Europa se ha caracterizado por ocuparse de aspectos específicos de la protección de los bienes culturales, de modo que los convenios adoptados complementan, en sectores determinados, la regulación más general de los textos de ámbito universal. En este sentido cabe mencionar el Convenio europeo para la protección del patrimonio arqueológico, hecho en Londres el 6 de mayo de 1969²1; el Convenio europeo sobre las infracciones relativas a los bienes culturales, hecho en Delfos el 23 de junio de 198522, el Convenio para la salvaguarda del patrimonio arquitectónico de Europa, hecho en Granada el 3 de octubre de $1985^{23}$, y la Convención europea para la protección del patrimonio arqueológico, hecha en La Valeta el 16 de enero de 1992.

La Comunidad Económica Europea, a través de la Directiva del Consejo de 27 de junio de 1985 relativa a la valoración del impacto ambiental de determinadas obras públicas o particulares, señala entre los elementos a tomar en consideración «los bienes materiales y el patrimonio cultural» (art. 3) ${ }^{24}$, fijando de este modo un nivel mínimo de protección ${ }^{25}$.

Aunque su labor tiene un carácter científico y prenormativo, no puede cerrarse esta referencia a las organizaciones intergubernamentales sin hacer alusión al trabajo del Instituto Internacional para la Unificación del Derecho Privado (UNIDROIT). Debe mencionarse la actividad consultiva que desarrolló en relación con el Convenio de La Haya de 1954 sobre la protección de los bienes culturales en tiempo de conflicto armado. En los últimos años se viene ocupando de los aspectos jurídicos de derecho civil relativos a la buena fe y a la transferencia de la propiedad en la adquisición de bienes culturales ${ }^{26}$. A petición de la UNESCO ha preparado un proyecto de convención en relación con los bienes culturales robados o ilícitamente exportados (Roma, 29 de septiembre-8 de octubre de 1993 $)^{27}$.

Por último, hay que tener presente la acción de las organizaciones internacionales no gubernamentales que tienen una actividad importante en el campo del tráfico ilícito de bienes culturales. El International Council of Museums (ICOM), organismo fundado en 1946 y que está asociado a la UNESCO, ha elaborado "códigos de conducta» para frenar el tráfico ilícito y promover la restitución de bienes culturales ${ }^{28}$, cuyo incumplimiento puede acarrear la expulsión del organismo. La difusión ha sido uno de los principales mecanismos que se ha promovido para paliar este problema. Tanto el boletín trimestral titulado Nouvelles de l'ICOM como la serie «Cent objets disparus / One hundred missing objects», iniciada en 1993 con el número dedicado a Angkor, han favorecido la localización de algunos de los bienes allí reseñados, que habían sido objeto de robo o pillaje. Obviamente, una parte del éxito de operaciones como ésta depende de que la obra sustraída hubiera sido, con anterioridad, debidamente inventariada, lo que implica, naturalmente, el haberse fotografiado. En 1975 se creó la International Organization for the 
Protection of Works of Art (IOPA) con la finalidad de prevenir las actividades delictivas que tengan por objeto las obras de arte mediante el establecimiento de un sistema de catalogación-inventario de los bienes artísticos. La actuación de estos organismos se complementa con la labor de la organización internacional de policía criminal Interpol, que ha prestado importantísimos servicios en la represión del tráfico ilícito de obras de arte.

Las fuentes internacionales relativas a la protección de los bienes culturales constituyen un conjunto de normas de naturaleza heterogénea. Éste es un ámbito que cuenta con pocas normas internacionales consuetudinarias de validez universal, circunscritas sobre todo - como se verá- al campo del derecho de los conflictos armados. Los convenios internacionales se inscriben en un contexto en el que su eficacia se ve condicionada por la incidencia de numerosos aspectos multidisciplinarios que precisan ser coordinados con otros tratados internacionales o con las legislaciones internas de los Estados. También la coexistencia de normativas universales y regionales introduce otro elemento de complejidad. Las recomendaciones, y demás textos de carácter no vinculante, a la vez que son un factor de desarrollo de la normativa internacional, también proyectan una duda sobre el alcance de determinadas normas.

\section{La noción de «bienes culturales»}

La noción de bienes culturales o la expresión que los define globalmente como "patrimonio cultural» tiene un significado de contornos imprecisos que depende, en último término, de las normas que regulan dichos bienes.

No existe una noción unitaria de bienes culturales válida tanto para los derechos internos como para el derecho internacional público. Los derechos internos definen los bienes culturales en función de criterios temporales y/o en atención a criterios valorativos que destacan el carácter excepcional de dichos bienes. El criterio temporal adopta diversas modalidades: determinación de una antigüedad mínima (p. e.: obras de más de cien años de antigüedad), referencia a un período preciso (p. e.: obras anteriores a una determinada fecha) o pertenencia a una determinada época artística o histórica (p. e.: arte precolombino, aborigen, etc.). El criterio valorativo generalmente destaca la «importancia artística», «histórica» y/o «arqueológica» de las obras, pero algunas legislaciones ponen también de relieve otros elementos como, por ejemplo, la «importancia nacional», el «interés cultural», «el etnográfico», «el etnológico», «el paleontológico» o el «folklórico» de los bienes.

A tal efecto, una ojeada a los preceptos más destacados de la legislación española del siglo xx nos permite ver que a veces se ha recogido el criterio temporal y que en otras ocasiones se ha adoptado el criterio valorativo, ocurriendo también que, en algunos casos, haya sido la combinación de ambos elementos la solución establecida. Así, la Ley de excavaciones arqueológicas de 7 de julio de $1911^{29}$ protegía las «antigüedades», definidas como «todas las obras de arte y productos industriales pertenecientes a las Edades Prehistórica, Antigua y Media» (artículo 2), o sea, hasta la época de Carlos I, según precisó el artículo 2 del Reglamento aprobado por Real Decreto de 1 de marzo de $1912^{30}$, adoptándose, pues, un criterio temporal; el juicio valorativo también tuvo cabida, puesto que el mismo artículo 2 de la citada ley señala que también forman parte de su objeto «las ruinas de edificios antiguos que se descubran», «las hoy existentes que entrañen importancia arqueológica», así como «los edificios de interés artístico abandonados a los estragos del tiempo». En la Ley de 4 de marzo de $1915^{31}$, que protegía los «monumentos arquitectónicos artísticos», prevalecía el criterio valorativo, ya que por tales «se entiende [...] los de mérito histórico o artístico, cualquiera que sea su estilo [...]» (artículo 1). El Real Decreto Ley de 9 de agosto de 1926 sobre protección y conservación de la riqueza artística ${ }^{32}$, verdadero hito en la evolución legislativa española a lo largo del siglo xx por las aportaciones novedosas que contiene, se decanta por el criterio valorativo, ya que el ámbito objetivo de aplicación recae sobre el «Tesoro artístico arqueológico nacional», que se define como «el conjunto de bienes muebles e inmuebles dignos de ser conservados para la nación por razones de arte y cultura» (artículo 1); en la reglamentación de las exportaciones el párrafo segundo del artículo 26 introduce el criterio temporal al prescribir que se requerirá la autorización correspondiente si se quieren exportar «objetos y obras de pintura, decoración, dibujo, grabado, etc., de autores anteriores a mil ochocientos treinta», matización que resulta del todo innecesaria, como bien ha señalado J. M. Alegre Ávila ${ }^{33}$, por cuanto el artículo 28.2 ya contiene la obligación de conseguir autorización para poder exportar cualquier objeto cuya salida no estuviese prohibida. En el Real Decreto de 2 de julio de 1930 sobre la enajenación de obras artísticas, históricas o arqueológicas ${ }^{34}$ se recoge nuevamente el criterio valorativo al definir lo que se entiende como tales, puesto que después de enumerarlas, y para evitar que algún bien quede fuera de su regulación por no haber estado citado específicamente, añade que hay que incluir «todos los objetos que tengan interés de arte, historia o cultura» (artículo 2). La Constitución de la Segunda República Española, de 9 de diciembre de $1931^{35}$, dispone que «toda la riqueza artística e histórica del país, sea quien fuere su dueño, constituye tesoro cultural de la Nación y estará bajo la salvaguar-
26. Riccardo Monaco, «La contribution d'Unidroit à la protection internationale des biens culturels", International Sales of Works of Art / La Vente Internationale d'Oeuvres d'Art, coloquio celebrado en Ginebra entre el 11 y el 13 de abril de 1985 (dirigido por Pierre Lalive), Institute of International Business Law and Practice-Faculté de Droit de Genève, Ginebra, s.a., p. 567-572 (con un resumen en inglés en la página 573).

27. ICOM, Pillage en Afrique / Looting in Africa, Cent objects disparus / One hundred missing objects, ICOM, Maison de l'UNESCO, París, 1994, p. 140141; Martín Rebollo, op. cit., p. 63-65.

28. ICOM, Éthique des ac quisitions / Ethics of acquisitions, ICOM, París, 1971; Burnham, op. cit., p. 198-201. No fue hasta el 4 de noviembre de 1986, durante la $15^{\mathrm{a}}$ Asamblea del ICOM, reunida en Buenos Aires (Argentina), que el «Código de deontología profesional» fue adoptado. Véase ICOM, Statuts. Code de déontologie professionnelle, ICOM, Maison de l'UNESCO, París, 1987, p. 14-28, e ICOM, Codi d'ètica professional, colllecció Museus, Documentació, núm. 8, Generalitat de Catalunya, Departament de Cultura, Barcelona, 1994.

29. G., 8 de julio de 1911. Algunas de las principales normas de la legislación española que versan sobre los bienes culturales se hallan recogidas en el apéndice que figura al final de la obra de José Luis Álvarez Álvarez, La transmisión de obras de arte, serie J, Monografías prácticas de derecho español, vol. XLV, Editorial Revista de Derecho Privado, Madrid, 1975. Para la presente ley, véanse las páginas 269-271.

30. G., 5 de marzo de 1912. Álvarez Álvarez, op. cit., p. 271278.

31. G., 5 de marzo de 1915.

32. G., 15 de agosto de 1.926 . Álvarez ÁlvarEZ, op. cit., p. 278287.

33. Juan Manuel Alegre Ávila, Evolución y régimen jurídico del Patrimonio Histórico. La configuración dogmática de la propiedad bistórica en la Ley I6/1985, de 25 de junio, del Patrimonio Histórico Español, Colección Análisis y Documentos, núm. 5, t. 1, Ministerio de Cultura, Madrid, 1994, p. 91 (nota 68).

34. G., 5 de julio de 1930. Álvarez Álvarez, op. cit., p. 288-289.

35. Jorge de Esteban (ed.), Constituciones españolas y extranjeras, Biblioteca Política Taurus, vol. 38/I, Taurus, Madrid, 1979 ( $2^{\mathrm{a}}$ ed.; ed. original: 1977), p. 310-333.

36. G., 23 de mayo de 1931. Álvarez Állvarez, op. cit., p. 289291 
37. G., 12 de diciembre de 1931. Álvarez Álvarez, op. cit., p. 291 294.

38. G., 4 de julio de 1931.

39. G., 8 de julio de 1931.

40. G., 14 de julio de 1931.

41. G., 25 de mayo de 1933. Esta ley fue modificada por la de 22 de diciembre de 1955 ( $B O E, 25$ de diciembre de 1955). El texto de la ley del 33 aparece recogido en Álvarez Álvarez, op. cit., p 294-303, y en AA.VV., 50 años $d 6$ protección del patrimonio histórico artístico. $1933-1983$, Ministerio de Cultura, Madrid, 1983, p 71-79.

42. El texto definitivo del artículo 46 de la vigente Constitución de 1978 es el siguiente: «Los poderes públicos garantizarán la conservación y promoverán el enriquecimiento del patrimonic histórico, cultural y artístico de los pueblos de España y de los bienes que lo integran, cualquiera que sea su régimen jurídico y su titularidad. La ley penal san cionará los atentados contra este patrimonio». ESTEBAN, op. cit., p. 425.

43. $B O E$ núm. 155 , de 29 de junio de 1985 (corrección de erratas en $B O E$ núm. 296, de 11 de diciembre de 1985). José Luis Álvarez Álvarez, Estudios sobre el patrimonio histórico español y la ley de 25 de junio de 1985 Civitas, Madrid, 1989, p. 839-862 (en este libro se contiene un detalladísimo estudio sobre misma); Ley del Patrimonio Histórico Español y Reales Decreto. de desarrollo parcial de la Ley. Ministerio de Cultura, Madrid, 1992, p. 7-33; Legislació..., p. 145-173. Para conocer el iter par lamentario en su elaboración. véase Ley del Patrimonio Histórico Español. Trabajos Parlamentarios (edición preparada por e letrado de las Cortes Generales Alfredo Pérez de Armiñán y de la Serna), serie I, núm. 21, Cortes Generales, Publicaciones de Congreso de los Diputados, Madrid, 1987

44. En la normativa autonómica también se recogen fórmulas parecidas de carácter omnicomprensivo. A tal efecto transcribimos solamente lo que preceptúa la Ley del Patrimonio Cultural Catalán de 30 de septiembre de 1993 (DOGC núm. 1807, de 11 de octubre de 1993): «El patrimoni cultural català és integrat per tots els béns mobles o immobles relacionats amb la història i la cultura de Catalunya que per llur valor històric, artístic, arquitectònic, arqueològic, paleontològic, etnològic, documental, bibliogràfic, científic o tècnic mereixen una protecció una defensa especials, de manera que puguin ésser gaudits pels ciutadans i puguin ésser transmesos en les millors condicions a les generacion futures» (art. 1.2), donde se aña- de que «també fan part del patrimoni cultural català els béns immaterials integrants de la cultura popular i tradicional i les particularitats lingüístiques, d'acord amb la Llei 2/1993, del 5 de març, de foment i protecció de la cultura popular i tradicional i de l'associacionisme cultural» (art. 1.3).

45. En los supuestos previstos por el artículo 49.2, y por razón del origen público, forman parte del Patrimonio Documental «los documentos de cualquier época»; para los «conservados o reunidos en el ejercicio de sus actividades por las entidades y asociaciones de carácter político, sindical o religioso y por las entidades, fundaciones y asociaciones culturales y educativas de carácter privado" es necesaria, para que puedan ser considerados como integrantes del Patrimonio Documental, «una antigüedad superior a los cuarenta años» (art. 49.3).

46. La actual legislación española distingue entre «bienes de interés cultural» $\mathrm{y}$ «bienes inventariados». Los bienes de interés cultural gozan «de singular protección y tutela» (art. 9.1 de la LPHE) y pueden ser objeto de declaración por ministerio de la Ley (Disposiciones adicionales primera y segunda de la LPHE) o mediante Real Decreto previo expediente administrativo (art. 9.2 de la LPHE). Los «bienes inventariados» son los bienes muebles del patrimonio histórico que deben incluirse en el inventario general en función de su «singular relevancia» (art. 26 de la LPHE). Los «bienes de interés cultural» no pueden ser objeto de exportación (art. 5.3 de la LPHE), salvo para exposiciones temporales o permutas autorizadas (arts. 31 y 34 de la LPHE). Los «bienes inventariados» precisan autorización expresa para su exportación (art. 5.2 de la LPHE y art. 45.2 del Real Decreto de 10 de enero de 1986 de desarrollo parcial de la LPHE y que en adelante mencionaremos como RPHE) y su transmisión deberá comunicarse a la Administración (art. 26.6.c de la LPHE). También requerirán la autorización expresa para su exportación aquellos bienes que tengan incoado expediente para su inclusión en el inventario general (art. 45.2 del RPHE). Los demás bienes del patrimonio histórico no quedan afectados por estas limitaciones, salvo si tienen más de cien años de antigüedad, en cuyo caso, para poder ser exportados, será necesario que la Administración lo autorice expresamente (art. 5.2 de la LPHE y art. 45.2 del RPHE); asimismo, la Administración puede declarar como inexportables algunos bienes del patrimonio histórico «como medida cautelar hasta que se incoe expediente para incluir el bien en alguna de las categorías de protección especial previstas en esta Ley» (art. 5.3 de la LPHE), o sea, la relativa a los bienes de interés cultural o la existente cuando los bienes se han in- cluido en el inventario general del artículo 26 de la LPHE.

Para el texto del RPHE, véase $B O E$ núm. 24, de 28 de enero de 1986 (corrección de erratas en $B O E$ núms. 26 y 53 , de 30 de enero y 3 de marzo de 1986); Álvarez Álvarez, Estudios sobre elpatrimonio histórico español..., p. 863-897; Ley del Patrimonio Histórico Español y Reales Decretos de desarrollo parcial de la Ley, p. 35-83; Legislació..., p. 145-173 (faltan varios de los anexos).

Sobre la noción de los bienes culturales y la terminología empleada en relación con los mismos por las legislaciones nacionales hasta principios de los años setenta, puede consultarse BURNHAM, op. cit., p. 27-159 (categoría 2).

47. La naturaleza mueble o in mueble de ciertos bienes puede tener gran importancia en la determinación de la competencia judicial de los tribunales en las reclamaciones planteadas en casos de tráfico ilícito de bienes culturales. En el asunto de las pinturas murales de Casesnoves, la competencia de los tribunales franceses dependía de si las mismas, extraídas de una capilla románica situada en Francia y trasladadas a Suiza, debían considerarse un bien mueble o inmueble. Véase la sentencia de la Cour de Cassation de 15 de abril de 1988, Revue critique de droit international privé, t. 78, núm. 1 (1989), p. 100111 (nota de Georges A. L. Droz). Sobre esta decoración pictórica procedente de la iglesia, actualmente desafectada, de San Salvador de Casesnoves, véase el estudio realizado por Pere Ponsich en Catalunya Romànica. El Rosselló, vol. XIV, Enciclopèdia Catalana, Barcelona, 1993, p. 243, donde se recoge la bibliografia específica publicada con anterioridad.

48. Italo Carlo Angle, «Evolución del concepto de patrimonio cultural en Europa», Actas de las I Jornadas de Patrimonio Histórico-Artístico, t. I, Consejo General de Castilla y León, Burgos, 1982, p. 53-69, concretamente la página 53.

49. Jean-Pierre Babelon; André Chastel, «La notion de patrimoine», Revue de l'art, núm. 49 (1980), p. 5-32 (los autores limitan su estudio al ámbito francés); Domingo J. Buesa Conde, «El Patrimonio Cultural. Reflexiones en torno a su concepto y evolución", Aragonia Sacra, III (1988), p. 91-136; ANGLE, op. cit., passim.

50. Joan Prat Carós, «Antigalles, relíquies i essències: reflexions sobre el concepte de patrimoni cultural», Revista d'Etnologia de Catalunya, núm. 3 (1993), p. 122 131, concretamente la página 122.

51. «Relazione della commissione d'indagine per la tutela e la valorizzazione del patrimonio storico, archeologico, artistico, e del paesaggio", Rivista trimestrale di diritto pubblico, año XVI,

dia del Estado [...]. El Estado protegerá también los lugares notables por su belleza natural o por su reconocido valor artístico o histórico» (artículo 45), reflejándose, pues, el criterio valorativo. En el Decreto de 22 de mayo de $1931^{36}$ y en la Ley de 10 de diciembre del mismo año ${ }^{37}$, referidos a las enajenaciones de los bienes artísticos, arqueológicos e históricos, se recoge un criterio cronológico, estableciéndose determinados requisitos para poder efectuar las enajenaciones de inmuebles u objetos artísticos, arqueológicos o históricos de una antigüedad mayor de cien años por parte de las entidades y personas jurídicas, ya sean eclesiásticas o civiles (artículo 1 del decreto y de la ley), y también, según la mencionada ley, que contenía una regulación más restrictiva que la del decreto, las realizadas por los particulares (artículo 1 de la ley) e incluso por las compañías mercantiles dedicadas al comercio de antigüedades, salvo —en este último caso- si se trata «de meros objetos industriales y de escaso valor artístico, arqueológico o histórico» (criterio valorativo), siempre y cuando «no actúen por encargo, comisión o agencia de las comprendidas en el artículo 1 de la presente Ley» (artículo 17 de la ley). En el lapso de tiempo existente entre ambos se promulgó el Decreto de 3 de julio de $1931^{38}$, donde, con la modificación establecida por el Decreto de 7 de julio de $1931^{39}$ y la aclaración de la Orden de 11 de julio del mismo año ${ }^{40}$, se prescribió la prohibición temporal de exportar al extranjero objetos artísticos, arqueológicos o históricos que fueran anteriores a 1830 y tuvieran un precio de venta superior a las 50.000 pesetas, dando, por tanto, acogida al criterio cronológico y al valor económico. En la Ley de 13 de mayo de 1933, sobre defensa, conservación y acrecentamiento del patrimonio histórico-artístico nacional ${ }^{41}$, que ha sido el eje nuclear de la legislación española en materia de patrimonio cultural durante más de medio siglo, se combina el criterio temporal y el 
tal y bibliográfico, los yacimientos y zonas arqueológicas, así como los sitios naturales, jardines y parques, que tengan valor artístico, histórico o antropológico» ${ }^{44}$. Para la exportación de bienes que integran el Patrimonio Histórico Español con más de cien años de antigüedad y, en todo caso, para los inscritos en el Inventario General de bienes muebles es indispensable, tal como prescribe el artículo 5.2 de esta ley y siempre y cuando no se trate de bienes declarados de interés cultural o inexportables (artículo 5.3), la autorización expresa y previa por parte de la Administración, recogiéndose, pues, el criterio cronológico, ya tradicional en la legislación española, de un tiempo superior a la centuria, elemento que también se recoge para que los documentos conservados o reunidos por cualquier persona sean considerados como integrantes del Patrimonio Documental (artículo 49.4) ${ }^{45}$.

En las legislaciones internas la protección jurídica de los bienes culturales de mayor relieve se suele complementar con un acto administrativo de identificación de dichos bienes seguido de su inclusión en un registro especial ${ }^{46}$.

Los textos internacionales posteriores a la Segunda Guerra Mundial han generalizado las expresiones «bienes culturales» $\mathrm{y}$ «patrimonio cultural», pero no han logrado dar una significación única a dichos términos. Aunque, por su propio objeto, la Convención del 17 de noviembre de 1970 sobre las medidas que deben adoptarse para prohibir e impedir la importación, la exportación y la transferencia de propiedad ilícitas de bienes culturales se refiere a bienes muebles y la Convención del 23 de noviembre de 1972 para la protección del patrimonio mundial cultural y natural regula bienes inmuebles, otras convenciones universales, como el Convenio de La Haya de 1954 para la protección de los bienes culturales en caso de conflicto armado, o tratados de ámbito regional, regulan unitariamente los bienes culturales, tanto muebles como inmuebles ${ }^{47}$.

Los textos internacionales suelen prescindir del carácter público o privado de los bienes, así como de la pertenencia o vinculación de un bien a una determinada comunidad. Sin embargo, la Convención de la UNESCO de 1970 para la represión del tráfico ilícito de bienes culturales otorga excepcionalmente una protección específica a los bienes públicos (artículo 7.b.I) e introduce la noción de «países de origen» de los bienes culturales (artículo 2) en función de determinados criterios de «pertenencia» expresamente enunciados en el Convenio (artículo 4). La fórmula más comúnmente empleada por los textos internacionales es la enumeración de distintas «categorías» de bienes culturales, rebasando el concepto de «obras de arte» con la incorporación de bienes de interés arqueológico, numismático, etnológico, paleontológico, etc.
Estas enumeraciones no taxativas, de carácter eminentemente flexible y ejemplificador, se complementan con una remisión al derecho interno en virtud de la cual los Estados pueden ampliar los bienes protegidos con otros no expresamente enumerados en los convenios internacionales.

En los derechos internos se distingue, como nociones dotadas de una cierta autonomía, entre bienes culturales y bienes ambientales. Éstos últimos serían los lugares naturales o paisajes que, en función de su importancia desde el punto de vista científico o estético, gozan de una específica protección jurídica. Un reflejo de esta distinción en el plano internacional se encuentra en la Convención de 1972 sobre la protección del patrimonio mundial cultural y natural, que define separadamente el «patrimonio cultural» (artículo 1) y el «patrimonio natural» (artículo 2).

Esta fragmentación de la noción de bienes culturales en función de los distintos textos que los regulan no ha sido obstáculo para los intentos de formulación de una noción global de los mismos. En este sentido, diversos autores se han esforzado por dar un concepto de lo que debe entenderse por «bienes culturales» o por "patrimonio cultural». Suele tratarse de definiciones amplias y algo ambiguas, como la propuesta por I. C. Angle, que considera el «patrimonio cultural, o histórico-artístico, arqueológico, bibliográfico o natural» como «un conjunto de objetos, lugares o testimonios a los que nosotros, portadores de la cultura de una época determinada, atribuimos un valor y un significado particular con respecto a la otra realidad que nos rodea ${ }^{48}$. En la presente definición se da cabida al componente sujetivo, que además variará a lo largo de la historia ${ }^{49}$. En un intento de clarificación, J. Prat Carós llegó a la conclusión que aquellos bienes que consideramos que deben ser protegidos y que conforman el patrimonio cultural son aquéllos que se perciben como escasos ${ }^{50}$, caracterización que si bien funciona en algunos casos, no constituye un rasgo que por sí solo, si no va acompañado de otras cualidades, sirva para identificarlos.

Entre las tentativas de formulación de un concepto unitario de bienes culturales merece destacarse la labor realizada en Italia por la «Comisión de investigación para la tutela y la valoración de las cosas de interés histórico, arqueológico, artístico y del paisaje», llamada Comisión Franceschini, creada en 1964. Fruto de sus trabajos fue una propuesta, formulada en términos de una declaración, en la que los bienes culturales se definen mediante una enumeración de los distintos tipos que los integran (bienes de interés arqueológico, histórico, artístico, ambiental y paisajístico, archivístico y bibliográfico) seguida de una noción genérica en virtud de la cual deberían considerarse bienes culturales los «bienes que constituyan testimonio material dotado de valor de civilización ${ }^{51}$. Se trata núm. 1 (1966), p. 119-244, concretamente la página 143 ; Tommaso Alibrandi; Piergiorgio FERRI, I beni culturali e ambientali, Teoria e Pratica del Diritto, sección IV, núm. 9, Giufrè Editore, Milán, 1978, p. 13. 
52. Massimo Severo Giannini, "I beni culturali», Rivista trimestrale di diritto pubblico, año XXVI, fasc. núm. 1 (1976), p. $3-38$, concretamente las páginas 25-26.

53. Emer de VatTel, Le Droit des Gens, ou Principes de la Lo Naturelle, appliqués à la conduite et aux affaires des Nations et des Souverains, tomo II, Londres. 1758, libro III, capítulo IX, parágrafo 168 (consultado a través de la reimpresión realizada por Slatkine Reprints-Henry Dunant Institute, Ginebra, 1983).

54. Pietro VerRI, «La suerte de los bienes culturales en los conflictos armados. De la Antigüedad a la Segunda Guerra Mundial (II)», Revista Internacional de la Cruz Roja, núm. 69 (1985), p. 127-139, concretamente las páginas 127 130 y 132; FRIGO, op. cit., p. 72 73. El texto de la Declaración de Bruselas del 1874 aparece en L. Friedman, The Law of War. A Documentary History, vol. I, Nueva York, 1972, p. 194 y s. de una noción omnicomprensiva, precisa y sintética que puede aplicarse también en el ámbito internacional. Desde el punto de vista dogmático jurídico no refleja, sin embargo, lo que jurídicamente caracteriza a los bienes culturales. Con gran rigor el profesor M. S. Giannini ha dicho que en los bienes culturales existen unos «intereses de naturaleza patrimonial», es decir, son cosas que pertenecen a alguien — poderes públicos o particulares- que tiene derechos de disposición y de disfrute que están regulados por normas de derecho común: de derecho privado si el bien es de propiedad particular o de derecho administrativo si el bien es público. Por otro lado, el bien es el elemento material de «intereses de naturaleza inmaterial y pública», como son los intereses culturales. En función de estos intereses sobre el bien cultural los poderes públicos tienen potestades que no se refieren a su uso patrimonial, sino a su conservación y a su disfrute por el mundo de la cultura ${ }^{52}$. Quizás esta caracterización de los bienes culturales sea un buen punto de partida para su consideración desde la perspectiva del derecho internacional público y pueda servir para examinar en qué medida el ordenamiento jurídico introduce en estos intereses de naturaleza pública una dimensión internacional. En efecto, la soberanía del Estado y los intereses colectivos de la comunidad internacional suponen intereses públicos adicionales, a veces contradictorios, que deben ser tomados en cuenta en cualquier consideración que aspire a ser completa de la regulación jurídica de los bienes culturales.

\section{La conservación de los bienes culturales. Normas internacionales en caso de conflicto armado}

La guerra constituye una situación en la que los bienes culturales se encuentran expuestos a los mayores peligros. Los monumentos y bienes culturales inmuebles pueden ser destruidos en el curso de las hostilidades como consecuencia de los bombardeos. Las obras de arte y demás bienes culturales muebles pueden ser objeto de botín, saqueo o expolio durante las hostilidades o al término del conflicto armado.

Ya en los autores clásicos se encuentran manifestaciones de condena de los daños innecesarios para la victoria causados a monumentos y edificios de importancia artística. E. de Vattel decía que en el curso de las hostilidades «deben salvaguardarse los edificios que honran a la humanidad y que no contribuyan a hacer más potente al enemigo ${ }^{53}$.

Durante la segunda mitad del siglo XIX se percibe un interés creciente por codificar el derecho de la guerra, en tanto en cuanto se constataba la insuficiencia de las prácticas consuetudinarias imperantes hasta entonces. Un eslabón importante en este proceso fue la Declaración sobre las leyes y costumbres de la guerra adoptada al final de la Conferencia de Bruselas celebrada entre el 27 de julio y el 27 de agosto de 1874. El germen de la misma se hallaba en un reglamento interno norteamericano, que influyó también en las ordenanzas militares promulgadas con posterioridad por otros países. Me estoy refiriendo a las Instructions for the Government of the Armies of the United States in the Field, preparadas por el jurista Francis Lieber y aprobadas en Washington el 24 de abril de 1863. En la Declaración de Bruselas del 1874 se establecía que los bienes destinados al culto, a obras de caridad, a la educación, a las artes y a las ciencias, aun cuando fuesen de titularidad pública, deben gozar del mismo tratamiento que los de propiedad privada, esto es, tienen que ser respetados, siendo castigados por las autoridades competentes los que transgredieran tal precepto (artículo 8). En la eventualidad de un asalto o de un bombardeo se consideró que había que tomar todas las medidas necesarias conducentes a preservar, en lo posible, los edificios dedicados a las artes, a las ciencias y a fines caritativos, así como los hospitales y centros de acogida de heridos y enfermos, siempre y cuando no se utilizaran también con una finalidad militar, siendo un deber de los asediados el indicar la existencia de tales edificios a través de signos distintivos visibles, que han de comunicarse previamente al enemigo (artículo 17). Además, el saqueo se declaró como contrario al derecho internacional (artículos 18 y 39) y se prohibió cualquier destrucción o requisa de los bienes del enemigo que no encontrara una justificación en una imperativa necesidad de guerra (artículo 13.g). Sin embargo, la Declaración de Bruselas no fue ratificada por ningún Estado, por lo que nunca constituyó un instrumento jurídico obligatorio. También merece citarse el denominado Manuel des lois de la guerre sur terre, aprobado en Oxford el 9 de septiembre de 1880 por el Instituto de Derecho Internacional, que, respecto a los bienes culturales, contiene normas similares a las contenidas en la Declaración de Bruselas ${ }^{54}$.

Este proceso culmina en la normativa salida de las dos primeras conferencias internacionales de la paz celebradas en La Haya. Se trata del Reglamento sobre Leyes y Costumbres de la Guerra Terrestre anexo a la II Convención de 29 de julio de 1899 , aprobado en la I Conferencia Internacional de la Paz, del Reglamento sobre el mismo asunto anexo a la IV Convención de 18 de octubre de 1907, aprobado en la II Conferencia Internacional de la Paz, y de la IX Convención del 18 de octubre de 1907 sobre el bombardeo de objetivos terrestres por las fuerzas navales, aprobada también en la II Conferencia Internacional de la Paz. 
Las normas establecidas en los reglamentos anejos a las Convenciones de La Haya de 1899 y 1907, además de la prohibición de atacar las «ciudades abiertas» (artículo 25 de los reglamentos anexos a la II Convención de 1899 y a la IV Convención de 1907), preceptuaban la obligación, para el supuesto de un asedio o bombardeo, de tomar todas las medidas necesarias para respetar, dentro de lo posible, los edificios consagrados a los cultos, a las artes, a las ciencias y a la beneficiencia, los monumentos históricos, los hospitales y los lugares en donde se hallen reunidos los heridos y enfermos, salvo que dichos edificios estuvieran destinados al mismo tiempo a algún fin militar, y para ello indicaba que tales edificios y sitios debían ser señalados con apropiados signos distintivos, comunicados previamente al enemigo (artículo 27 de los reglamentos anejos a la II Convención de 1899 y a la IV Convención de 1907). Una regulación similar aparecía en la IX Convención de 1907, donde su artículo 1 impone la prohibición de atacar las «ciudades abiertas» (tal prescripción queda, sin embargo, sometida a los límites establecidos en el artículo 2 de la misma Convención) y su artículo 5 contiene el mismo precepto protector de determinados edificios y lugares que encontramos en el artículo 27 de los reglamentos anejos a la II y IV convenciones de La Haya, y fija que los monumentos, edificios o lugares que deben ser respetados en los bombardeos por fuerzas navales serán identificados a través de signos visibles, que consistirán en paneles rectangulares, divididos diagonalmente en dos triángulos, siendo negro el superior y blanco el inferior. También el artículo 56 de los reglamentos anejos a la II y IV convenciones de La Haya, aplicable a la ocupación, contiene una regulación protectora de determinados bienes, entre los cuales se hallan los culturales, determinándose la prohibición de cualquier requisa, destrucción o daño intencionado de tales bienes, incluso si son muebles, y aunque la titularidad sea del Estado. La práctica del botín de guerra carece de legitimación, por cuanto el saqueo aparece formalmente prohibido (artículos 28 y 47 del Reglamento anejo a la IV Convención de 1907 y artículo 7 de la IX Convención de 1907). De toda esta regulación se deriva una protección de los bienes culturales inmuebles y muebles, que gozan de un régimen privilegiado, en tanto en cuanto que se les aplica el tratamiento que tienen los bienes de propiedad privada, aun cuando se trate de bienes de titularidad pública. Sin embargo, todas estas obligaciones se hallaban sometidas a las importantes limitaciones generales de los convenios consistentes en la cláusula si omnes, en virtud de la cual sus disposiciones sólo eran aplicables si todos los beligerantes eran partes de las convenciones (artículo 2 de la IV Convención de 1907 y artículo 8 de la IX Convención de 1907), y la excepción de «las necesidades milita- res» (artículo 23.g del Reglamento anejo a la IV Convención de 1907, para el estado de hostilidades, y artículo 2, párrafo tercero, de la IX Convención de 1907), aparte de la restricción impuesta al considerarse que solamente era aplicable su normativa para el supuesto de una «guerra», de manera que quedaban fuera de su ámbito los conflictos armados no identificados como tal, cualquiera que fuera su causa. En caso de incautación, destrucción o deterioro intencionado de los bienes sujetos a protección, entre los cuales se encuentran los culturales, se preveía un régimen de responsabilidad penal individual para los autores (artículo 56, párrafo segundo, de los reglamentos anejos a la II y IV convenciones de La Haya). La contravención de las disposiciones reglamentarias daba lugar a una indemnización de tipo económico, siendo el Estado beligerante responsable por todos los actos cometidos por los miembros de sus fuerzas armadas (artículo 3 de la IV Convención de 1907) ${ }^{55}$.

Algunos años más tarde, concretamente el 9 de agosto de 1913, el Instituto de Derecho Internacional aprobó, en Oxford, un manual similar al de 1880, pero en esta ocasión referido a la guerra naval, donde se intentaba ampliar la reglamentación existente ${ }^{56}$.

La trágica experiencia de la Primera Guerra Mundial hizo que en los años siguientes se formularan diversos proyectos para otorgar una protección más efectiva a los bienes culturales. En este sentido merece destacarse el informe elaborado en 1918 por la Sociedad Neerlandesa de Arqueología, que propugnó la creación de un organismo internacional que realizara un inventario de los monumentos y edificios que debieran ser preservados, siempre que no se utilizaran con finalidades militares ${ }^{57}$.

Otra iniciativa importante está constituida por las denominadas «Reglas de La Haya», proyecto de normas sobre la guerra aérea redactado en 1923 por una comisión de expertos, pero que nunca fue ratificado. En caso de bombardeos aéreos su artículo 25 dispone que deben tomarse todas las medidas necesarias para respetar, dentro de lo posible, los edificios destinados al culto, a las artes, a las ciencias y a la beneficiencia, así como los monumentos históricos, siempre y cuando no se utilicen al mismo tiempo con alguna finalidad militar, para lo cual tales edificios deberán identificarse con signos distintivos que sean visibles, incluso de noche, desde las aeronaves, consistiendo en un panel rectangular, dividido diagonalmente, formando, por tanto, dos triángulos, de color negro el superior y blanco el inferior. Se trata, pues, de una regulación muy similar a la contenida en el artículo 27 de los reglamentos sobre Leyes y Costumbres de la Guerra Terrestre anejos a la II y IV convenciones de La Haya de 1899 y 1907, y en el artículo 5 del IX Convenio relativo al bombardeo por las fuerzas navales. Además del monumento o grupo de monumentos que merecen protección,
55. Para el texto de las convenciones, véase Friedman, op. cit., p. 204 y s.

56. NAHLIK, op. cit., p. 97; VERRI, «La suerte de los bienes culturales en los conflictos armados. De la Antigüedad a la Segunda Guerra Mundial (II)», Revista..., p. 131 y 132

57. Para el texto del proyecto, véase Revue générale de droit international public, XXVI (1919), p. 329-336. 
58. Para las «Reglas de la Haya», véase Rivista di diritto internazionale (1923), p. 40 y s.

59. OEA Serie Tratados, núm. 33 Doc. OEA/Ser. A/52a 8SEPF). La denominación de "Pactc Roerich» se debe al nombre del artista ruso, nacido en San Petersburgo y residente en Nue va York, Nicolas Roerich, que encomendó, de acuerdo con e neoyorquino museo Roerich, la preparación de un convenio al jurista Georges Chklaver.

60. Art et Archéologie. Recueil de Législation Comparée et de Droit International, núm. 2 (1940), p. $60 \mathrm{y} \mathrm{s.}$

61. Respecto a las medidas protectoras adoptadas por el gobierno republicano, que contó con la inestimable ayuda del pueblo, así como en relación con el traslado de las obras de arte desde Madrid —entre ellas la colección del Museo del Prado-y otros lugares hasta Valencia, desde donde se transportarían posteriormente hacia Figueres (Girona), Peralada (Girona) y otros puntos del norte de Cataluña, véase Imma Julí́n, «La protección del patrimonio artístico durante la guerra civil (por el Gobierno de la República)», Boletín del Museo e Instituto "Camón Aznar", IV (1981), p. 38-63, y Arturo ColoRado Castellary, «Le trésor artistique pendant la guerre civile espagnole de Madrid à Figueras 17 juillet 1936-3 février 1939», en el catálogo de la exposición conmemorativa Du Greco à Goya Chefs d'oenvre du Prado et des collections espagnoles, Musée d'Art et d'Histoire, Genève, 16 juin-24 septembre 1989, Éditions d'Art Albert Skira, Ginebra, 1989, p. 169-200. En relación con la salida de nuestro país de estas obras artísticas con destino al $\mathrm{Pa}$ lacio de las Naciones de Ginebra, desde donde deberían ser devueltas al Gobierno efectivo en España, una vez terminado el conflicto interno, me remito al testimonio directo de Miguel A. Marín "Así salvamos los tesoros del Museo del Prado», Historia y Vida, año XXI, núm. 241 (1988), p. 70-78, así como a François LACHENAL, "Le trésor artistique pendant la guerre civile espagnole, 4 février-1er septembre 1939», en el catálogo de la exposición conmemorativa $\mathrm{Du}$ Greco à Goya..., p. 201-213. Nótese que la evacuación hacia el extranjero de tales bienes tuvo lugar en febrero de 1939, muy poco tiempo después de haberse concluido la elaboración del proyecto de convenio por el Office International des Musées. Sobre los sucesivos traslados de las principales obras del Prado, véase también NichOLAs, op. cit., p. 50 (el Castillo de Peralada aparece mencionado, erróneamente, como de Peñalda) y 52 (p. 66, 67, 69 y 70 en la traducción francesa). también puede determinarse que debe respetarse la zona contigua a los mismos, de una anchura máxima de 500 metros, con la condición de no utilizarse con fines militares, lo cual será comprobado por una comisión de vigilancia formada por tres representantes neutrales (artículo 26). Con la introducción de la noción de «objetivo militar», que legitima su bombardeo por parte del enemigo (en el artículo 24 se especifica lo que este proyecto entiende como tal), se viene a superar la distinción de la reglamentación de La Haya de 1899 y 1907 entre localidades defendidas y localidades no defendidas o «ciudades abiertas ${ }^{58}$.

Por su importancia histórica la Convención para la protección de las instituciones artísticas y científicas, así como de los monumentos históricos, más generalmente conocida como el «Pacto Roerich», abierto a la firma en Washington el 15 de abril de 1935, supone un hito en la protección de los bienes culturales a partir de su suscripción por países del continente americano $0^{59}$. Dicho tratado consagra la neutralidad de los monumentos históricos, museos e instituciones científicas, artísticas, educativas y culturales, debiendo, por tanto, ser respetados y protegidos, para lo cual se identificarán a través de una bandera blanca que lleve un círculo rojo que incluya tres esferas rojas; los gobiernos signatarios elaborarán una lista de los monumentos e instituciones para los que se solicita la protección establecida en el Pacto, que cesará si los mismos son utilizados con fines militares.

El Office International des Musées, organismo del Institut International de Coopération Intellectuelle, elaboró en 1938 un proyecto de convención para la protección de los monumentos y de las obras de arte durante los conflictos armados, donde se estipula que su preparación debe efectuarse en tiempo de paz y basa la protección de determinados bienes en la ausencia de una verdadera utilidad militar en su destrucción. Este proyecto de convención determina el alejamiento de los bienes muebles del teatro de operaciones militares, su concentración en refugios especialmente habilitados al efecto, debidamente identificados mediante signos distintivos, así como, llegado el caso, las garantías jurídicas de su transporte al territorio de Estados terceros aun cuando el conflicto sea de orden interno. También regula la protección de que gozan los monumentos o grupos de monumentos, siempre que no se utilicen con fines militares. Una comisión internacional controlará e inspeccionará si se cumplen los preceptos previstos por la convención ${ }^{60}$. A través del redactado de este proyecto se vislumbra la influencia ejercida por los acontecimientos producidos durante la guerra civil española ${ }^{61}$, gracias a los cuales se avanzó en las técnicas de preservación de los bienes culturales. Con esta contienda se crearon, tal como apunta S. E. Nahlik, dos precedentes importantes: por un lado, el depósito en un país neutral, bajo los auspicios de una organización internacional, de los bienes culturales evacuados y, por otro, la devolución de los mismos al gobierno que se ha adueñado del poder y ha sido reconocido por un cierto número de Estados, que es distinto del que confió en depósito esos objetos ${ }^{62}$.

Iniciada ya la Segunda Guerra Mundial merece mencionarse el proyecto de convenio para la protección de los monumentos históricos preparado por la Asociación Internacional denominada Lieux de Genève, basado en buena medida en la experiencia aportada por la guerra civil española y el conflicto entre China y Japón ${ }^{63}$.

La Convención de La Haya de 14 de mayo de 1954 para la protección de los bienes culturales en caso de conflicto armado es el primer tratado de ámbito universal dedicado por completo a la protección de los bienes culturales, los cuales, a diferencia de la reglamentación internacional anterior, aparecen ya mencionados con esta terminología. Auspiciada por la UNESCO y calificada en su momento de "Cruz Roja de los monumentos», constituye el fruto de los esfuerzos realizados desde la segunda mitad del siglo XIx, inspirándose, según se estipula en el preámbulo, en los principios establecidos en las convenciones de $\mathrm{La}$ Haya de 1899 y 1907, así como en el denominado «Pacto Roerich» del 1935. Su articulado también deja entrever la influencia ejercida por las cuatro convenciones de Ginebra del 1949 relativas a la protección de las víctimas de los conflictos armados. En el mismo preámbulo, tras reconocerse que los bienes culturales han sufrido importantes daños a causa de los conflictos armados y que como consecuencia de los avances técnicos se encuentran cada vez más amenazados de destrucción, todo lo cual supone un menoscabo al patrimonio cultural de la humanidad entera - en este sentido se adopta acertadamente un enfoque claramente universalista, superándose las concepciones nacionalistas, mucho más restrictivas en cuanto a la protección de los bienes culturales- ${ }^{64}$, se considera la conveniencia de su protección internacional, de manera que la misma debe ya organizarse, para que sea efectiva, en tiempo de paz, comprometiéndose los Estados signatarios a tomar todas las medidas protectoras apropiadas, tanto nacionales como internacionales.

La Convención de La Haya de 1954 se presenta como un texto que armoniza y complementa las convenciones anteriores (artículo 36) y establece una protección que constituye un estándar mínimo que no puede ser objeto de acuerdos posteriores derogatorios in pejus (artículo 24) ${ }^{65}$. Establece un régimen que aspira a una aplicación lo más general posible al abandonar toda referencia a la cláusula si omnes (artículo 18.3), por lo cual la Convención será aplicable a todos los Estados Parte aun 
cuando una de las potencias implicadas en la contienda no la haya ratificado (respecto a ésta también se aplicará la Convención por parte de los Estados Parte, siempre que unilateralmente declare la aceptación de sus principios y los aplique, tal como determina el mismo artículo 18.3), y contemplar su aplicación a cualquier conflicto armado surgido entre dos o más Estados signatarios, aunque alguno de ellos no reconozca el estado de guerra (artículo 18.1), y a los conflictos de carácter no internacional, como mínimo en relación con las obligaciones de respeto de los bienes culturales (artículo 19), así como a los casos de ocupación de un territorio enemigo, aun cuando no haya resistencia militar (artículo 18.2). Con esta concepción se superan algunos de los defectos de que adolecían la mayoría de los proyectos y normativas positivas elaborados con anterioridad.

La presente Convención adopta, en su artículo 1 , una noción de los bienes culturales que no toma en consideración ni el origen ni el régimen de propiedad (pública o privada). Partiendo de estas premisas, los divide en tres categorías, citando diversos ejemplos:

a) «Los bienes, muebles o inmuebles, que tengan una gran importancia para el patrimonio cultural de los pueblos», criterio dotado de una buena dosis de ambigüedad, que queda disipada en gran medida a través de su especificación, puesto que el mismo párrafo continúa diciendo que merecen tal consideración «los monumentos de arquitectura, de arte o de historia, religiosos o seculares, los campos arqueológicos, los grupos de construcciones que por su conjunto ofrezcan un gran interés histórico o artístico, las obras de arte, manuscritos, libros y otros objetos de interés histórico, artístico o arqueológico, así como las colecciones científicas y las colecciones importantes de libros, de archivos o de reproduccciones de los bienes antes definidos»;

b) los edificios que contengan dichos bienes, como museos, grandes bibliotecas y depósitos de archivos, entrando también en esta categoría los refugios destinados a protegerlos en el supuesto de un conflicto armado;

c) centros que contengan una gran cantidad de bienes culturales comprendidos en los dos apartados anteriores, que se denominarán «centros monumentales», refiriéndose a determinadas áreas o a los barrios históricos de algunas grandes ciudades, incluso a toda la superficie de ciertas ciudades históricas (Florencia, Venecia, Brujas, etc.).

Así, pues, esta Convención adopta un criterio valorativo (gran importancia para el patrimonio cultural, el interés histórico, el artístico, el arqueológico) a la hora de hacer el elenco de los bienes culturales incluidos en la primera categoría. En aras de extender el ámbito de protección también considera como bienes culturales los edificios que los contengan, independientemente de si los mismos tienen o no importancia cultural o interés histórico, artístico o arqueológico (segunda categoría). En tercer lugar, merecen asimismo tal consideración los denominados «centros monumentales», en base al gran número de bienes culturales que albergan. Pero no son sólo los bienes culturales así definidos los que, según la Convención, deben gozar de protección, sino que la misma también se extiende a los medios de transporte utilizados para su traslado, ya sea en el interior de un Estado o hacia otro distinto (artículos 12 y 13), y al personal encargado de tutelar esos bienes (artículo 15).

Los bienes culturales así definidos disfrutan, según el Convenio, de una protección que puede ser de dos clases: la general o la denominada "protección especial».

La protección general consiste en las obligaciones de salvaguardia y respeto de los bienes culturales (artículo 2). Se entiende por «salvaguardia» la adopción en tiempo de paz, por parte del Estado poseedor de tales bienes, de las medidas apropiadas para preservar los bienes culturales situados en su propio territorio contra los efectos previsibles de un conflicto armado (artículo 3). La Convención también prevé que, en el supuesto de ocupación, el ocupante deberá, dentro de lo posible, prestar su apoyo a las autoridades nacionales competentes del país ocupado, para asegurar la salvaguardia y conservación de los bienes culturales (artículo 5.1) y que, en caso de que se requiriera una actuación urgente para conservar bienes culturales que hubiesen sufrido daños en el curso de las hostilidades, de la cual no pudieran encargarse las autoridades nacionales competentes del territorio ocupado, el ocupante adoptará, en estrecha colaboración con esas autoridades, las medidas más necesarias para su conservación (artículo 5.2); vemos que se trata de una regulación que, con la finalidad de evitar los abusos de los ocupantes, dota de gran capacidad de actuación a las autoridades nacionales de los territorios ocupados, siendo muy restrictiva en relación con aquéllos, que sólo tienen competencia a título subsidiario. La obligación de «respeto», que deben cumplir los Estados signatarios en relación con los bienes culturales situados tanto en su propio territorio como en el de los otros Estados parte de la Convención, consiste en abstenerse de utilizar los bienes culturales, sus sistemas de protección y sus proximidades inmediatas a un uso que pudiera exponer tales bienes a su destrucción o deterioro en caso de conflicto armado (por tanto, el precepto no se refiere sólo a un destino militar, sino también a cualquier otro que pudiera acarrear que los bienes culturales se vieran afectados de destrozo o daño), deber que incumbe al Estado posesor, y de cualquier acto de
62. NAHLIK, op. cit., p. 105.

63. VERRI, «La suerte de los bienes culturales en los conflictos armados. De la Antigüedad a la Segunda Guerra Mundial (II)», Revista..., p. 135 y 136; FrIGO, op. cit., p. 88 (nota 46).

64. Tras la adopción de la Carta de las Naciones Unidas (firmada el 26 de junio de 1945 en San Francisco, entró en vigor el 24 de octubre de ese mismo año) aparecen diversos instrumentos internacionales que ponen de manifiesto la idea de que la humanidad tiene intereses en determinados sectores, conformándose la noción de "patrimonio común de la humanidad». Sobre su evolución, naturaleza jurídica, ámbitos de aplicación y principios normativos que derivan del mismo, véase Antonio Blanc Altemir, El Patrimonio Común de la Humanidad. Hacia un régimen juridico internacional para su gestión, Bosch, Barcelona, 1992, passim; respecto al patrimonio cultural, que por carecer del elemento de exclusión de soberanía se ha denominado "patrimonio común de la humanidad por afectación", véanse especialmente las páginas 167-178. Sobre la concepción internacionalista del patrimonio cultural, que es la adoptada por la Convención de La Haya del 54, y la nacionalista, que es la expresada, por ejemplo, en la Convención del 70 sobre las medidas que deben adoptarse para prohibir e impedir la importación, la exportación y la transferencia de propiedad ilícitas de bienes culturales, véase John Henry Merryman, "Two Ways of Thinking about Cultural Property», American Journ al of International Law, vol. 80, núm. 4 (1986), p. 831-853.

65. Frigo, op. cit., p. 96. 
66. Jean DE BREUCKeR, «Pour les vingt ans de la Convention de $\mathrm{La}$ Haye du 14 mai 1954 pour la protection des biens culturels", Revue belge de droit international, vol. XI (1975-2), p. 525-547, concretamente las páginas 533 y 535 .

La Convención dispone que el gobierno que sea considerado como legítimo por los miembros de un movimiento de resistencia operando en territorio ocupado deberá, si es posible, indicar a éstos la obligación de cumplir con las disposiciones de respeto de lo bienes culturales establecidas en el tratado (art. 5.3).

En base al contenido del preám bulo de la Convención, el deber de respeto de los bienes culturales se hace incluso extensible, según M. Frigo (op. cit., p. 98), a los situados en el territorio de Estados que no la han ratificado

67. Los artículos 12-16 del Reglamento de ejecución de esta Convención de 1954 (el mismo forma parte integrante de ésta, según se estipula en su artículo 20) regulan lo relacionado con este registro.

A tenor de lo dispuesto en el artículo 13.2 del Reglamento el Estado ocupante puede también solicitar la incripción en el registro.

68. Para la descripción del emblema, su uso, ya sea de manera aislada o repetido tres veces en for mación de triángulo, y su colocación, véanse los artículos 16 y 17 de la Convención y los artículos 20 y 21 de su Reglamento de ejecución.

69. El artículo 12.2 de la Convención establece que el transporte que esté sometido al régimen de protección especial estará sujetc a la inspección internacional en la forma determinada en el Reglamento (por tanto, tal como prevén los artículos 1-10 del mismo) y que los convoyes deberán ostentar el emblema de la Con vención. El artículo 12.3 señala que los Estados parte de la Convención «se abstendrán de todo acto de hostilidad contra un transporte efectuado bajo protec ción especial», precepto que sirve para reiterar y, de esta forma. reforzar la inmunidad de que goza el transporte bajo protección especial.

70. Jean DE BREUCKER, «La réserve des nécessités militaires dans la Convention de La Haye du 14 mai 1954 sur la protection des biens culturels», Revue de droit pénal militaire et de droit de la guerre, vol. XIV-1-2 (1975), p. 255-264 (con resúmenes en otras lenguas en las páginas 265-269), concretamente las páginas 261-262; ídem «Pour les vingt ans...», p. 537.

Sobre la cláusula de la necesidad militar y los esfuerzos por com binarla con unos principios mínimos de humanidad, véase G.I A. D. DRAPER, «Military necessity and humanitarian imperatives». Revue de droit pénal militaire et de droit de la guerre, vol. XII - 2 (1973), p. 129-142 (con resúmenes en otras lenguas en las páginas 143-151), passim. hostilidad respecto de dichos bienes, exigencia que atañe al adversario (artículo 4.1). Asimismo, los Estados signatarios se comprometen a prohibir, impedir y, en caso necesario, hacer cesar cualquier acto de robo, pillaje, ocultación o apropiación indebida de bienes culturales, así como todo acto de vandalismo que se cierna sobre ellos, quedando igualmente prohibidas las requisas de bienes culturales muebles sitos en el territorio de otro Estado parte de la Convención (artículo 4.3) y toda medida de represalia contra los bienes culturales (artículo 4.4). Todas estas obligaciones de respeto deben aplicarse por parte de los Estados parte de la Convención incluso en relación con un Estado signatario que no haya cumplido con las obligaciones de salvaguardia impuestas por el artículo 3 del tratado (artículo 4.5). Es más, incluso en el caso de que el adversario, contraviniendo lo preceptuado por la Convención, haya utilizado algún bien cultural con fines militares, la exigencia de respeto para con el mismo dentro del marco de la protección general subsiste ${ }^{66}$.

Existe un número limitado de bienes que, además de gozar del sistema de protección general, disfrutan de algunos privilegios en tanto en cuanto les es aplicable el régimen de «protección especial». Éste está previsto para «un número restringido de refugios destinados a preservar los bienes culturales muebles en caso de conflicto armado, de centros monumentales y otros bienes culturales inmuebles de importancia muy grande», siempre que se hallen alejados de grandes centros industriales o de objetivos militares importantes y no sean, además, utilizados para fines militares (artículo 8.1). Este rigor queda matizado, puesto que también podrán gozar de protección especial, cualquiera que sea su situación, los refugios para bienes culturales muebles que se hallen construidos de tal manera que, según todas las probabilidades, no sean susceptibles de padecer daños en el caso de bombardeos (artículo 8.2). Además, aun en el caso de que alguno de los bienes culturales antes citados se encontrara situado cerca de un objetivo militar importante, podrá aplicársele el régimen de protección especial, siempre que el Estado solicitante se comprometa a no usar ese objetivo en caso de conflicto armado, especificándose que, si se tratase de algún puerto, estación ferroviaria o aeródromo, deberá desviar del mismo todo tráfico, actividad cuya preparación se efectuará en tiempo de paz (artículo 8.5). Se prevé la creación de un «Registro internacional de bienes culturales bajo protección especial» (artículo 8.6), que conservará el director general de la UNESCO, en el que las partes contratantes puedan inscribir, a través de un procedimiento contradictorio, los bienes que pretendan situar bajo dicho régimen más estricto de protección. El requisito de la inscripción en el mencionado registro, que normalmente efectuará el Estado posesor, es indispensable para que los bie- nes en cuestión gocen de tal protección especial ${ }^{67}$. Ésta supone la «inmunidad» para dichos bienes, absteniéndose las partes contratantes de cualquier acto de hostilidad respecto a ellos y de toda utilización de los mismos o de sus proximidades inmediatas con fines militares (artículo 9), obligación exigida a partir de su inscripción en el citado registro internacional, por lo que, a diferencia de los bienes sometidos a la protección general, ese deber negativo consistente en la abstención de usar los bienes culturales o sus proximidades inmediatas con fines militares debe ser cumplido también en tiempo de paz. Los bienes que se hallen en régimen de protección especial deberán ostentar el emblema de señalización establecido en el propio Convenio (artículo 10), identificación que es meramente potestativa para los bienes sujetos al régimen de protección general (artículo 6$)^{68}$, y podrán ser objeto de inspección y vigilancia internacional (artículo 10), en la forma prevista en los artículos 1-10 del Reglamento de ejecución de la presente Convención.

A lo ya dicho debe añadirse que, fuera del registro, también podrán gozar de protección especial los transportes que estén exclusivamente destinados al traslado de bienes culturales, tanto en el interior de un Estado como hacia otro (artículo 12.1), si se cumple lo preceptuado en el artículo 17 del Reglamento de ejecución de la Convención y, para el caso de traslado hacia el territorio de otro país, lo dispuesto, además, por el artículo 18 del citado Reglamento ${ }^{69}$; disfrutan igualmente de protección especial los refugios improvisados en el transcurso de un conflicto armado bajo las condiciones prescritas en el artículo 11 del Reglamento de ejecución.

La Convención de La Haya de 1954 tiene su talón de Aquiles en las excepciones incorporadas por consideraciones de realismo, que prevén la suspensión de las obligaciones en atención a las «necesidades militares». Respecto a los bienes culturales sometidos al régimen de protección general y en relación con las obligaciones de respeto definidas en el párrafo primero del artículo 4, existe la reserva «de que una necesidad militar impida de manera imperativa su cumplimiento» (artículo 4.2). Ciertamente no se trata de una reserva general y se limita exclusivamente a las obligaciones de abstenerse de utilizar los bienes culturales, sus sistemas de protección o sus proximidades inmediatas a una destinación que exponga tales bienes a destrucción o deterioro en caso de conflicto armado y de todo acto de hostilidad respecto a ellos, exigiéndose además el criterio de la imperatividad, sin que la reserva afecte a otras conductas como actos de pillaje, requisa o saqueo ${ }^{70}$. Con relación a los bienes sometidos al régimen de protección especial las necesidades militares se contemplan con mayor rigor. Debe tratarse de «casos excepcionales de ne- 
cesidad militar ineludible y mientras subsista dicha necesidad»; para mayor garantía la necesidad habrá de ser determinada en este caso por el jefe de una formación militar que como mínimo comprenda una división y, si las circunstancias lo permiten, la suspensión de la inmunidad se notificará a la parte adversaria con una antelación suficiente (artículo 11.2). Aparte del cumplimiento de todos estos requisitos se exige que la parte que haya suspendido la inmunidad lo notifique, en el plazo más breve posible, por escrito y explicando los motivos, al comisario general de bienes culturales (artículo 11.3). Aunque para algunos esta solución es globalmente satisfactoria ${ }^{71}$, otros, como S. E. Nahlik, han señalado amargamente la paradoja de que es un pobre consuelo pensar que, si supuestamente se dan las circunstancias antes indicadas, «incluso la más valiosa de las obras de arte puede ser destruida de acuerdo con los términos, quizás incluso en aplicación de la Convención para la protección de los bienes culturales» $»^{72}$.

También la denominada «conducta del adversario» puede provocar la suspensión de las obligaciones previstas por la Convención. Tal reserva sólo puede argüirse en relación con los bienes culturales sometidos a protección especial, siempre que se haya vulnerado alguno de los deberes establecidos en el artículo 9 de la Convención, y de una manera temporal en tanto en cuanto dure esa violación, exigiéndose además, siempre que sea posible, el requerimiento previo al adversario para que cese en dicha violación dentro de un plazo razonable (artículo 11.1). Al igual que sucede con la suspensión de la inmunidad de los bienes culturales bajo protección especial por causa de necesidad militar en los términos establecidos en la Convención, en el caso de la conducta del adversario la parte que suspenda la inmunidad deberá, dentro del plazo más breve posible, notificarlo por escrito al comisario general de bienes culturales, explicando las razones que han llevado a adoptar tal medida (artículo 11.3). ¿Por qué se ha limitado la reserva a los bienes culturales bajo protección especial? A ello se ha contestado diciendo que, debido al poco número de los bienes que disfrutan de este régimen, éstos son perfectamente conocidos, añadiendo que el Estado que solicita la inscripción en el registro se compromete solemnemente a no utilizarlos con fines militares, cometiendo un acto de perfidia si lo hiciera ${ }^{73}$.

Para el caso en que se viole alguno de los preceptos de la Convención, la misma contiene una clásula general que remite a los ordenamientos jurídicos internos de los Estados signatarios, por cuanto establece, en su artículo 28, que «las Altas Partes Contratantes se comprometen a tomar, dentro del marco de su sistema de derecho penal, todas las medidas necesarias para descubrir y castigar con sanciones penales o disciplinarias a las personas,

cualquiera que sea su nacionalidad, que hubieren cometido u ordenado que se cometiera una infracción de la presente Convención».

En términos generales puede decirse que el avance más significativo de la Convención de La Haya de 1954 consiste en la universalidad de su aplicación, en el sentido de que sus normas deben cumplirse en cualquier clase de conflicto armado, incluidos los no internacionales. Los dos protocolos adicionales a los convenios de Ginebra de 1949 relativos a la protección de las víctimas de los conflictos armados, que fueron adoptados el 8 de junio de 1977, confirman esta tendencia ${ }^{74}$. Además, ambos instrumentos contienen un precepto referido a la protección de los bienes culturales. En relación al Protocolo I, relativo a los conflictos armados internacionales, nos interesa su artículo 53, donde se dice que, sin perjuicio de la Convención de La Haya de 1954 y de otros instrumentos internacionales pertinentes, queda prohibido realizar cualquier acto de hostilidad respecto de los monumentos históricos, obras de arte y lugares de culto que constituyen el patrimonio cultural o espiritual de los pueblos, así como de utilizar estos bienes en apoyo del esfuerzo militar o de hacerlos objeto de medidas de represalia. El artículo 16 del Protocolo II, que se refiere a los conflictos armados internos, contiene una regulación similar, pues establece que, bajo reserva de las disposiciones contenidas en la Convención de La Haya de 1954, está prohibido cometer cualquier acto de hostilidad a los monumentos históricos, obras de arte y lugares de culto que constituyen el patrimonio cultural o espiritual de los pueblos y de destinarlos en apoyo del esfuerzo militar.

La regulación actual de la protección de los bienes culturales en caso de conflicto armado exigiría una reconsideración global del asunto. Hay que tener presente que potencias de la importancia de Estados Unidos o el Reino Unido no han ratificado todavía la Convención de La Haya de 1954. Deberían desarrollarse las disposiciones referentes a las sanciones penales, siendo de lamentar que en la Convención no se adoptaran las propuestas

71. Antonio Malintoppi, «La protezione «speciale» della Città del Vaticano in caso di conflitto armato", Rivista di diritto internazionale, vol. XLIII, fasc. 4 (1960), p. 607-629, concretamente la página 625 .

72. S.E. Nahlik, «On some Deficiencies of the Hague Convention of 1954 on the Protection of Cultural Property in the Event of Armed Conflict», Annuaire de l'AAA/Yearbook of the $A A A$, vol. 44 (1974), p. 100108 , concretamente las páginas 104 y 105.

73. NAHLiK, «La protection internationale...», p. 128; DE Breucker, «Pour les vingt ans...», p. 535-536.

74. Para el texto de los Protocolos, véase Revue Générale de Droit International Public, t. 82, núm. 1 (1978), p. 329-398. El Protocolo II también se encuentra en Araceli Mangas Martín, Conflictos armados internos y Derecho Internacional Humanitario, Acta Salmanticensia, Estudios Jurídicos, núm. 70, Ediciones Universidad de Salamanca, Salamanca, 1990, p. 184-192. España ha ratificado ambos Protocolos (BOE de 26 de julio de 1989 y de 7 de octubre de 1989). 
75. De Breucker, «Pour les vingt ans...», p. 545. Para una propuesta concreta de disposiciones de esta naturaleza, véase Umberto Meranghini, «La difesa dei beni culturali dall'offesa bellica», Revue de droit pénal militaire e de droit de la guerre, vol. VII-1 (1968), p. 133-144 (con resúmenes en francés e inglés en las páginas 145 y 146), passim.

76. Según advierte Ramón Paniagua Redondo (en «Regulación jurídico internacional de los bienes culturales en caso de conflicto armado: La Convención de La Haya de 14 de mayo de 1954», Iuris. Quaderns de Politica Jurídica, núm. 1 (1994), p. $403-$ 415 , concretamente las páginas 414 y 415), si un Estado parte de la Convención de La Haya de 1954 lo es también de los proto colos adicionales de 1977 a las convenciones de Ginebra de 1949 las cláusulas de reserva relativas a la conducta del adversario y a la necesidad militar «no desplegarán sus efectos derogatorios a la Convención", a causa de la protección de carácter absoluto que goza e patrimonio cultural y espiritual a tenor de lo dispuesto en los artí culos 53 del Protocolo I y 16 de Protocolo II. Esta inmunidad del patrimonio cultural y espiritua con un valor absoluto ya había sido señalada por Araceli MANgAS MARTín (op. cit., p. 122 ídem, «La regulación jurídica internacional de los conflictos ar mados sin carácter internacional», en La regulación jurídica internacional de los conflictos armados Oficina Autonòmica Creu Roja de Catalunya, Barcelona, 1992, p. 125-145, concretamente en la página 141) al analizar el mencionado artículo 16 del Protocolo II en relación con los conflictos armados internos.

77. Para conocer con más detall esta evolución, véase Charles DE VISSCHER, «La protection internationale des objets d'art et des monuments historiques. Deuxième partie», Revue de Drou international et de Législation comparée, troisième série, $\mathrm{t}$. XVI núm. 2 (1935), p. 246-288, especialmente las páginas $246-254$ y 270-272; NAHLiк, La protection..., p. 66-87, y FrIGO, op cit. p. 61-72.

78. De Visscher, op. cit., p. 272 288; NAнLIK, La protection..., p 98-102, y FrIGO, op cit., p. 78-82

79. De Visscher, op. cit., p. 288.

80. Sobre las actividades del «Einsatzstab Rosenberg» véase NichOlas, op. cit., passim.

81. The Department of State Bulletin, VIII, p. 21-22; LouisJacques ROLLET-ANDRIANE, «Les précédents», Museum, vol XXXI, núm. 1 (1979), p. 4-7, concretamente la página 7 (este número de la revista está dedicado monográficamente a la cuestión del retorno y la restitución de los bienes culturales). de incluir una lista de infracciones graves ni se prestara mayor atención a la represión penal de las mis$\mathrm{mas}^{75}$. Asimismo, la existencia de la cláusula de la conducta del adversario y sobre todo la relativa a la necesidad militar, que tan encendidas discusiones motivó en la fase preparatoria, constituyen cortapisas en la protección de los bienes culturales, que sería deseable superar ${ }^{76}$. Se echa de menos que la Convención no contenga precepto alguno sobre la cuestión de la restitución de los bienes culturales ilegalmente transferidos a otro país en caso de conflicto armado, relegando su regulación a un protocolo facultativo, tema que trataremos a continuación.

\section{La restitución de los bienes culturales. Normas internacionales en caso de conflicto armado}

En el derecho internacional clásico se admitía como un título válido de adquisición la apropiación de los bienes del enemigo (ius praedae). Los bienes del adversario, y en especial los bienes culturales, se hallaban sometidos a graves peligros, no sólo de destrucción como consecuencia de las hostilidades, sino también de pérdida por traslado a otros países.

En la triste historia de los expolios y saqueos hay casos célebres que ponen de manifiesto la magnitud de estos atentados. En 1622 las tropas de la Liga Católica se apropiaron de la Biblioteca Palatina de Heidelberg y trasladaron sus fondos a Roma. Posteriormente, los franceses se apoderaron de muchos de sus manuscritos, llevándoselos a París (1798), y más adelante fueron restituidos a Heidelberg (1815). No menos azares experimentó el famoso políptico del «Cordero místico» de los hermanos Van Eyck de la catedral de San Bavón de Gante. En 1794 los franceses se adueñaron de la parte central, que fue depositada en el Louvre, para ser finalmente devuelta a su emplazamiento original en 1815. Al año siguiente seis paneles laterales del políptico fueron vendidos a un anticuario. Comprados después por un coleccionista inglés, serían adquiridos en 1821 por el rey de Prusia Federico-Guillermo III para su exposición en el Museo de Berlín. En virtud del artículo 247 del tratado de Versalles fueron restituidos a Bélgica después de la Primera Guerra Mundial.

En la evolución del derecho de guerra se registra una progresiva limitación del botín de los vencedores. Desde la paz de Westfalia (1648) se desarrolla, especialmente en los tratados, el principio de la obligación de restitución de los archivos. Después de las guerras napoleónicas, en las que se llevó a cabo un auténtico expolio de los bienes culturales de Egipto y de los Estados italianos, se pro- duce una pérdida de la legitimidad del ius praedae. Los acuerdos entre Francia y los Estados italianos celebrados tras la campaña de Italia obligan a entregar determinadas obras de arte a título de «contribución de guerra», no de botín, y, en algún caso, como medida de represalia. Sin embargo, en el Congreso de Viena (1815) se adoptó el principio de la obligación de restitución de las obras de arte aun cuando existiesen tratados internacionales en virtud de los cuales hubieran sido entregadas a los franceses ${ }^{77}$.

Después de la Primera Guerra Mundial los tratados de paz confirman el principio de la obligación de restitución de los bienes culturales sustraídos. Los tratados de Versalles (artículo 238), Saint-Germain-en Laye (artículo 184), Neuilly-surSeine (artículo 126), Trianon (artículo 168), Sèvres (artículo 420), concluidos respectivamente con Alemania, Austria, Bulgaria, Hungría y Turquía, así como el tratado de Riga entre Rusia, Ucrania y Polonia (artículo 11), establecen esta obligación de restitución en términos muy amplios con la finalidad de reconstituir las colecciones y los elementos dispersos de obras artísticas. Esto explica que se restituyeran a sus países de origen obras adquiridas legalmente y bienes transferidos en épocas anteriores, respecto de los cuales debía excluirse la aplicación de la institución de la prescripción. De ahí que, según el artículo 247 (párrafo 2) del tratado de Versalles, Alemania restituyera a Bélgica, como ya se ha dicho, seis tablas laterales del políptico del «Cordero místico» de los hermanos Van Eyck en concepto de reparación de guerra por las obras de arte y monumentos destruidos por los alemanes durante el conflicto bélico; por la misma causa, y en aplicación del mencionado artículo, Alemania también debía devolver a Bélgica los paneles exteriores del tríptico de la «Santa Cena» de la iglesia de San Pedro de Lovaina, obra de Dierick Bouts, que por entonces se conservaban repartidos entre el Museo de Berlín y la Pinacoteca de Munich. Incluso en algunos tratados se establece que en caso de que los bienes que deben ser transferidos se hayan perdido o destruido, se aplicará la restitución por sustitución o equivalencia. Así se estipula, por ejemplo, en el citado artículo 247 (párrafo 1) del tratado de Versalles, en que Alemania se compromete a suministrar a la Universidad de Lovaina «los manuscritos, incunables, libros impresos, mapas y objetos de colección correspondientes en número y en valor a los objetos semejantes destruidos» durante el incendio de su biblioteca.

En algunos de los tratados de paz la obligación de restitución adopta un carácter —al menos formalmente- recíproco y se establece por igual para vencedores y vencidos. Con bastante frecuencia se prevé el nombramiento de comisiones técnicas y medios de solución de controversias o se deja la ejecución a las modalidades que se establezcan en acuer- 
dos posteriores. Es interesante el acuerdo entre Italia y Austria, celebrado el 4 de mayo de 1920 en aplicación del tratado de Saint-Germain-en-Laye, en el que se dice que «el Reino de Italia reconoce la conveniencia de evitar, en el interés superior y general de la civilización, la dispersión de las colecciones históricas, artísticas y arqueológicas de Austria que constituyen en su totalidad un organismo estético e histórico indivisible y célebre [...]», por cuanto significa el reconocimiento de intereses superiores a los puramente estatales en materia de la regulación de los bienes culturales ${ }^{78}$.

Del conjunto de la práctica posterior a la Primera Guerra Mundial, el profesor Charles de Visscher deducía las siguientes orientaciones: por un lado, se tiende a favorecer la reconstitución de las obras de arte cuyas partes han sido dispersadas y a considerar la intangibilidad de las colecciones que forman un conjunto orgánico, donde el agrupamiento tiene un valor universal con independencia de su vinculación a un determinado país, en atención, en ambos casos, a los intereses generales del arte o de la ciencia. Por otro lado, los tratados han sancionado en algunas ocasiones el principio de una repatriación general de las obras de arte a sus países de origen o a los lugares de cuyo patrimonio forman parte. Sin embargo, esta vinculación es un criterio muy vago y difícil de determinar, porque la relación de una obra de arte con un país puede establecerse en virtud de múltiples razones (el asunto tratado, la nacionalidad o los orígenes del artista, su vinculación con la historia nacional, la tradición artística en que se inspire, su afectación a un emplazamiento específico o a un uso determinado). En consecuencia, la repatriación con esta finalidad, más que una norma, debe contemplarse como un criterio inspirador de las negociaciones que vayan a celebrarse en esta materia ${ }^{79}$.

Durante la Segunda Guerra Mundial adquirió triste fama el denominado «Einsatzstab Rosenberg» (Einsatzstab der Dienststellen des Reichleiters Rosenberg), organismo teóricamente creado para la protección de las obras de arte y que practicó una política sistemática de saqueo de bienes públicos y privados. Alfred Rosenberg fue uno de los criminales de guerra condenados por el tribunal militar internacional de Nuremberg ${ }^{80}$. El 5 de enero de 1943 los aliados adoptaron una declaración donde advertían formalmente que no reconocerían efectos jurídicos a las transferencias de todo tipo de bienes, comenzando por las obras de arte, que se hubieran efectuado en los territorios ocupados a través de actos de pillaje, aun cuando fueren cometidos de manera solapada, comprometiéndose, además, a cooperar en materia de restitución $^{81}$. En este sentido, los tratados de paz y los acuerdos posteriores a la guerra siguieron inspirándose en los criterios de restitución de los bienes culturales, sin tener en cuenta posteriores trans-

ferencias y su adquisición por terceros, así como reconociendo por lo general la admisibilidad de la restitución por sustitución o equivalencia a través de un objeto del mismo género y similar valor al destruido o perdido ${ }^{82}$.

La cuestión de la restitución de los bienes culturales tras el cese de las hostilidades se reguló en el Protocolo facultativo a la Convención de La Haya de 1954 para la protección de los bienes culturales en caso de conflicto armado. La adopción de un protocolo facultativo se justificó, por un lado, por la firmeza del principio general consuetudinario que obliga a la restitución $\mathrm{y}$, por otro, por la complejidad del problema dadas sus posibles conexiones con el tráfico ilícito de bienes culturales, que hacía suponer que no era factible llegar a un acuerdo general ${ }^{83}$.

Cada uno de los Estados contratantes del protocolo se compromete a impedir la exportación de los bienes culturales situados en un territorio que ha ocupado durante un conflicto armado (I, núm. 1); a embargar los bienes culturales importados en su territorio que procedan, ya sea directa o indirectamente, de cualquier territorio ocupado (I, núm. 2); a restituir, una vez hayan terminado las hostilidades, a las autoridades competentes del territorio anteriormente ocupado aquellos bienes culturales que se hallaban en su territorio y hubieran sido ilícitamente exportados, sin que quepa en ningún caso retenerlos a título de reparaciones de guerra (I, núm. 3), y a indemnizar a los poseedores de buena fe de los bienes culturales que deban ser restituidos, obligación que, en el redactado definitivo, recae sobre el Estado que tenía el deber de impedir la exportación de los bienes culturales del territorio que había ocupado (I, núm. 4) ${ }^{84}$.

En el Protocolo también se prevé que en caso de que un Estado parte deposite bienes culturales en el territorio de otro Estado contratante, con el propósito de protegerlos de los peligros de un con-

82. Véanse, por ejemplo, los artículos 12 y 75 del Tratado de Paz con Italia firmado en París el 10 de febrero de 1947. Para el texto, véase United Nations Treaty Series / Nations Unies. Recueil des Traités, vol. 49, p. 3 y s.

E. Foundoukidis, La reconstruction sur le plan culturel, $\mathrm{Pa}$ rís, 1945, p. 22 y s. (cit. por NAHLIK, La protection..., p. 148 , nota 2), opina que, tratándose de bienes culturales, la restitución por sustitución o equivalencia debe efectuarse mediante otra obra del mismo artista que la destruida o perdida o, en su defecto, de la misma escuela.

83. Si bien España ratificó la Convención de La Haya del 54 el día 9 de junio de 1960, no fue hasta el 1 de junio de 1992 cuando se adhirió a su protocolo facultati- vo (BOE núm. 178, de 25 de julio de 1992). Reproducido en Aranzadi. Repertorio cronológico de Legislación, L 1992, vol. III Aranzadi, Pamplona, 1.992, marginal 1.655, p. 6.130-6.132.

84. En el proyecto se preceptuaba que esta indemnización debía ser sufragada por el Estado que solicitaba la restitución, lo cual motivó obviamente una dura oposición por parte de los países que habían sufrido la ocupación. Es mucho más coherente que sea el antiguo ocupante quien deba correr con la carga de la indemnización si se tiene en cuenta que es a él, según lo dispuesto en el Protocolo (I, núm. 1), a quien concernía impedir la exportación de los bienes culturales del territorio que había ocupado. 
85. En relación con este cambio, véase Ramón Paniagua RedonDO, «El uso de la fuerza armada: su regulación jurídica internacional», en La regulación jurídica internacional de los conflictos armados, Oficina Autonòmica Creu Roja de Catalunya, Barcelona, 1992, p. 11-31.

86. Asbjorn EIDE, «Outlawing the Use of Force: The Efforts by the United Nations», The United Nations and the Maintenance of International Peace and Security, United Nations Institute for Training and Research, Martinus Nijhoff Publishers, DordrechtBoston-Lancaster, 1987, p. 99 145 , especialmente la página 144

87. Ramon Paniagua, "Consideracions sobre la Convenció de l'Haia de 1954», De Musens. Quaderns de Museologia i Museografia, núm. 4 (1993), p. 8-13, concretamente las páginas $12-13$. flicto armado, éste último deberá, al término de las hostilidades, devolverlos a las autoridades competentes del territorio de procedencia (II, núm. 5).

De todas maneras, un Estado parte del Protocolo puede no estar sometido a todas estas obligaciones apuntadas, por cuanto que en el momento de la firma, ratificación o adhesión puede declarar que no se sujetará a las disposiciones contenidas en la parte I (por tanto, núms. 1-4) o a las de la parte II (por tanto, núm. 5) del Protocolo (III, núm. 9).

\section{A modo de conclusión}

Si bien es cierto que desde la antigüedad hasta nuestros días ha habido una lenta pero progresiva evolución que ha conducido desde el ius ad bellum hacia el ius contra bellum ${ }^{85}$, no menos evidente es que actualmente los conflictos armados, donde personas y bienes se hallan amenazados de toda suerte de infortunios, muchas veces en contravención de la normativa internacional, constituyen una realidad. Y ello pese a los intentos de las organizaciones gubernamentales y no gubernamentales por erradicarlos. En este sentido destaca la labor ejercida por las Naciones Unidas, de la cual son miembros casi todos los Estados soberanos del mundo y cuyo principal interés gira en torno a la prohibición del uso de la fuerza, de acuerdo con lo dispuesto en el artículo 2.4 de la Carta. Sin embargo, es de notar que buena parte de sus esfuerzos tienen escasa relevancia práctica, debido fundamentalmente a que no penetran de manera incisiva en el problema estructural del poder en la sociedad internacional contemporánea, siendo la carrera armamentística su principal componente ${ }^{86}$. A pesar de que desde 1945 han sido muy pocos los conflictos armados habidos entre Estados, los de orden interno, en cambio, han proliferado de manera abrumadora y a menudo con una gran virulencia. Teniendo presente que los países «civi- lizados» pueden en cualquier momento estar implicados en algo tan «incivilizado» como es una guerra, ya sea intestina o internacional, emergiendo, pues, el postulado hobbiano de que «el hombre es un lobo para el hombre» (bomo homini lupus), son loables todos los esfuerzos encaminados a la protección de las personas y de los bienes que se han ido desarrollando a lo largo de los tiempos y que se han traducido en una normativa positiva, tanto a nivel estatal como supraestatal. ¿Es suficiente la tutela internacional de que disfruta actualmente el patrimonio cultural en caso de conflicto armado? Pienso que la respuesta debe contestarse negativamente y más aún teniendo en cuenta el reciente conflicto habido en la antigua Yugoslavia, país que había ratificado la Convención de La Haya de 1954 y su Protocolo facultativo el día 13 de febrero de 1956 , por lo que toda esta normativa internacional le era aplicable ${ }^{87}$. La Convención de La Haya del 54 contiene una reglamentación que, aparte de los defectos ya señalados en su momento, va quedando obsoleta a medida que se van sucediendo los avances tecnológicos en el terreno armamentístico. Por otro lado, hay Estados que todavía no la han ratificado. Mientras haya políticos más preocupados por desarrollar el potencial militar de sus respectivos países que por fomentar la cultura, lo cual encuentra su reflejo en las partidas que en los presupuestos de cada Estado tienen asignados ambos ámbitos, no parece que se pueda zanjar o, por lo menos, reducir el grave problema que supone el deterioro y, sobre todo, la destrucción de los bienes culturales, que, recordémoslo una vez más, son, según se deriva de la Convención de La Haya antes mencionada, patrimonio común de la humanidad. Nosotros no somos sino meros depositarios o detentores de los mismos, que tenemos siempre la obligación moral y ética, incluso cuando en alguna ocasión no encuentre el conveniente respaldo jurídico, de conservarlos para las generaciones venideras. 